San Jose State University

SJSU ScholarWorks

Master's Theses

Master's Theses and Graduate Research

Summer 2017

\title{
Illegal Dumping as an Indicator for Community Social Disorganization and Crime
}

Amory Anne Brandt

San Jose State University

Follow this and additional works at: https://scholarworks.sjsu.edu/etd_theses

\section{Recommended Citation}

Brandt, Amory Anne, "Illegal Dumping as an Indicator for Community Social Disorganization and Crime" (2017). Master's Theses. 4835.

DOI: https://doi.org/10.31979/etd.9hq7-yrq7

https://scholarworks.sjsu.edu/etd_theses/4835

This Thesis is brought to you for free and open access by the Master's Theses and Graduate Research at SJSU ScholarWorks. It has been accepted for inclusion in Master's Theses by an authorized administrator of SJSU ScholarWorks. For more information, please contact scholarworks@sjsu.edu. 


\title{
ILLEGAL DUMPING AS AN INDICATOR FOR COMMUNITY SOCIAL DISORGANIZATION AND CRIME
}

\author{
A Thesis \\ Presented to \\ The Faculty of the Department of Environmental Studies \\ San José State University \\ In Partial Fulfillment \\ of the Requirements for the Degree \\ Master of Science
}

by

Amory Brandt

August 2017 
(C) 2017

Amory Brandt

ALL RIGHTS RESERVED 
The Designated Thesis Committee Approves the Thesis Titled

\title{
ILLEGAL DUMPING AS AN INDICATOR FOR COMMUNITY SOCIAL DISORGANIZATION AND CRIME
}

\author{
by \\ Amory Brandt \\ APPROVED FOR THE DEPARTMENT OF ENVIRONMENTAL STUDIES \\ SAN JOSÉ STATE UNIVERSITY
}

August 2017

Rachel E. O’Malley, Ph.D.

Department of Environmental Studies

Jason Douglas, Ph.D.

Department of Environmental Studies

Anna Szabo, M.S.

Supervising Environmental Services

Specialist, Integrated Waste

Management Division, City of San

José 


\section{ABSTRACT \\ ILLEGAL DUMPING AS AN INDICATOR FOR COMMUNITY SOCIAL DISORGANIZATION AND CRIME \\ by Amory Brandt}

Illegal dumping of household waste in and around city streets results in many negative health, economic, and environmental effects. This goal of this study was to understand the systemic causes of illegal dumping within San José, California. Illegal dump sites were identified, quantified, characterized, and mapped within urban census block groups at a range of median family income levels. Results showed that commonly dumped debris types were furniture, and garbage. The most illegal dumping occurred within census block groups with low median family incomes, high percentages of nonEnglish speaking individuals, and high percentages of renters. Factors such as social disorganization, inequitable levels of garbage service, and lack of awareness of free city programs could be causing illegal dumping within San José. Illegal dumping was also more prevalent in areas with occurrences of petty crime. This study concluded that illegal dumping has the potential to serve as a visual representation of social disorganization and crime within communities. 


\section{ACKNOWLEDGMENTS}

This thesis would not have been possible without the support I have received from my family, friends, advisors, and coworkers. To my parents, thank you for the sacrifices you have made to give me access to years of education. Erik, thank you for selflessly giving me your time, support, and patience. Beth, Zander, Haley, Tattie, and Patty, thank you for countless supportive conversations, and much needed laughs.

Thank you, Rachel, Anna and Jason, for your expertise, and belief in my abilities. Thank you to the City of San José Staff who were always willing to give advice: Anne, Michael, Jerry, Ed. Thank you to my former students, who taught me more than I taught them. And lastly, thank you to the San José State students who helped collect data: David, Heather, Susan, Robert, Dionnie, Nicole, Elizabeth. 


\section{TABLE OF CONTENTS}

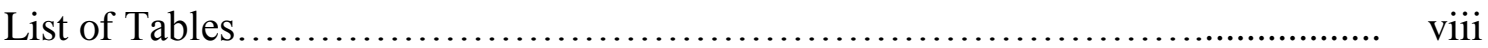

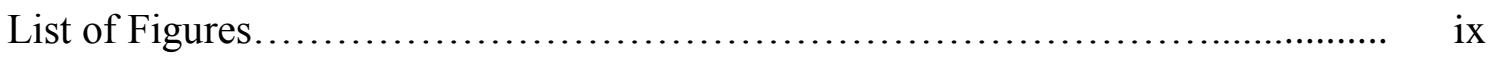

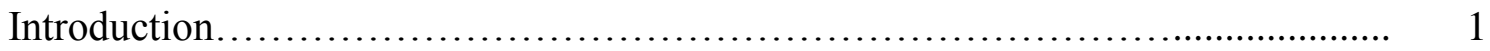

Literature Review........................................................... 2

Institutionalized Racism..................................................... 2

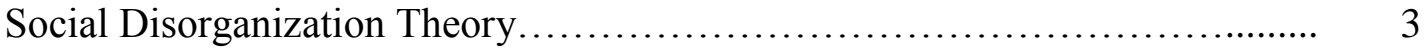

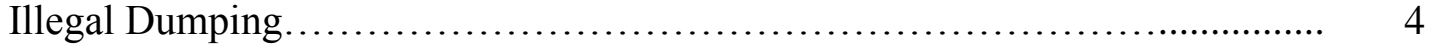

What is illegal dumping?.................................................................... 4

Effects of illegal dumping.............................................. 4

Causes of illegal dumping.......................................... 5

Problem Statement................................................................... 8

Research Objectives............................................................. 9

Research Questions and Hypotheses.............................................. 9

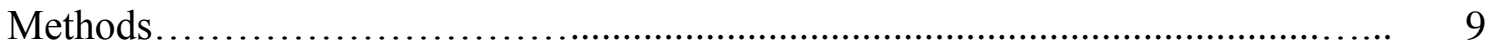

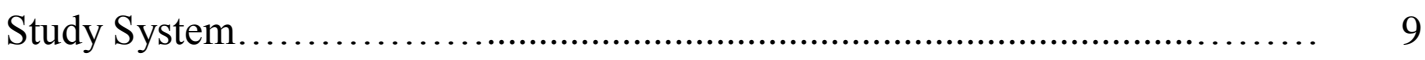

Study Design.................................................................... 12

Selecting census block groups............................................. 12

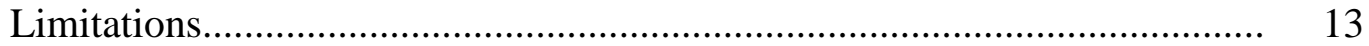

Data Collection.................................................................... 15

Primary data collection.................................................. 15

Identification of illegal dump sites............................................. 15

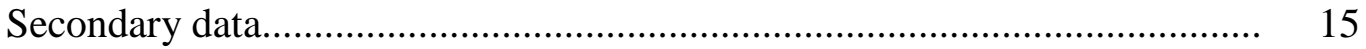

Demographic data.............................................................. 16

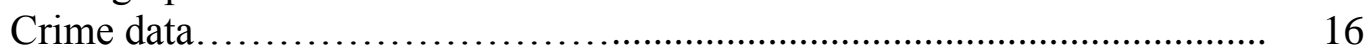

Geographic information systems data.................................. 17

Data Analysis..................................................................... 17

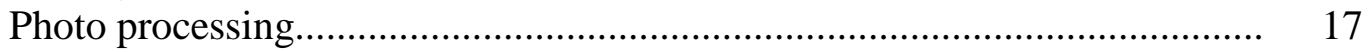

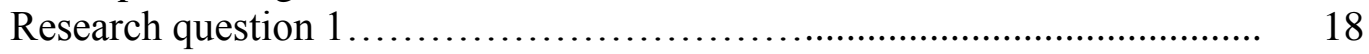

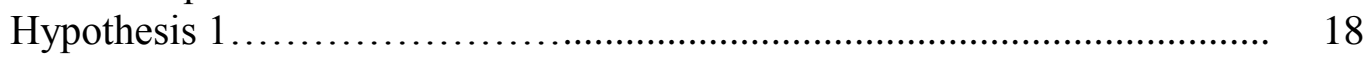

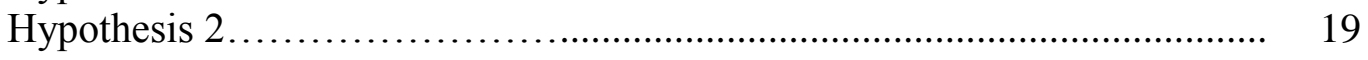

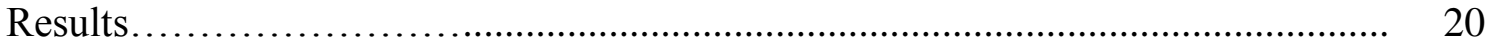

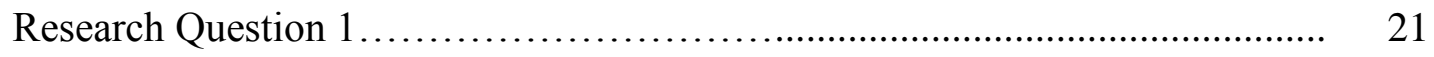

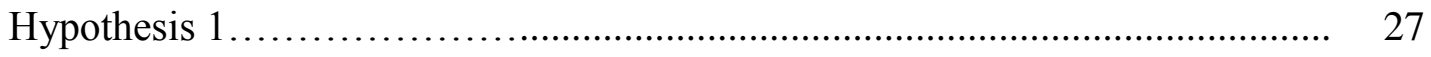

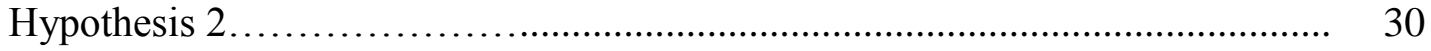


Discussion............................................................................ 31

Furniture and Garbage Were Most Commonly Dumped..................... 31

Illegal Dumping and Social Disorganization.................................... 33

Illegal Dumping and Crime.......................................................... 35

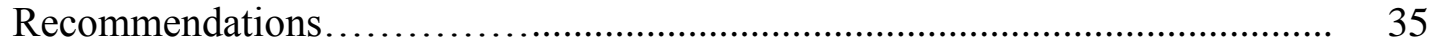

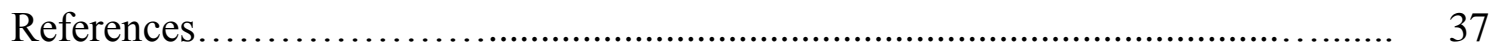




\section{LIST OF TABLES}

Table 1. Composition of Other Debris Types Measured Between all Sampled Block Groups............................................................

Table 2. Correlations Between Median Family Income, Percent Renters, and Percent Non-English Speaking Residents............................ 35 


\section{LIST OF FIGURES}

Figure 1. Figure 1: Map of the San Francisco Bay Area, from ESRI and Amory Brandt (2017)

Figure 2. $\quad$ Forty census block groups were sampled within San José, California, from Amory Brandt, City of San Jose, United States Census Bureau (2017)

Figure 3. Example photograph of single illegal dump site 16

Figure 4. Sampled census block groups by median family income, San José, California, 2016, from Amory Brandt, United States Census Bureau, City of San Jose (2017).

Figure 5. Percent composition of debris dumped throughout all sampled block groups

Figure 6. Distribution of illegally dumped furniture by income category......

Figure 7. Distribution of illegally dumped garbage by income category.......

Figure 8. Distribution of illegally dumped small appliances (vacuum, microwave, toaster oven) by income category

Figure 9. Distribution of illegally dumped large appliances (refrigerator, oven/stove, dishwasher) by income category

Figure 10. Distribution of illegally dumped mattresses by income category... 26

Figure 11. Distribution of illegally dumped yard trimmings by income ......... 26

Figure 12. Distribution of illegally dumped electronics by income category... 27

Figure 13. Mass of illegally dumped debris versus median family income..... 28

Figure 14. Mass of illegally dumped debris versus percent renters.

Figure 15. Mass of illegally dumped debris versus non-English speaking residents.

Figure 16. Illegal dumping compared to occurrences of crime within block groups 


\section{Introduction}

The greatest amount of waste is generated within industrialized countries because of high populations, and standards of living (Wang, 2014). Americans generate an average of $2 \mathrm{~kg}(4.41 \mathrm{lbs}$.) per capita per day of waste, compared to $0.37 \mathrm{~kg}(0.82 \mathrm{lbs}$.) per capita per day in less developed countries (Wang, 2014). Highly industrialized countries such as the United States have developed advanced waste management systems driven by demands for resource recovery, public health, and environmental well-being (Wilson, 2007). Regulation of waste collection, transportation, processing and disposal lessens the environmental impact of waste generation on the environment (Wang, 2014).

When waste is disposed of in violation of regulations, it is known as illegal dumping. Illegal dumping is the intentional disposal of waste in non-permitted areas, such as sidewalks, streets, creeks, fence lines, forests, or open pits (Matos, Ostir, \& Kranjc, 2012; Matsumoto \& Takeuchi, 2011; United States Environmental Protection Agency, 1998; Webb, Marshall, Czarnomski, \& Tilley, 2006). Within the State of California, individuals caught dumping can be fined up to $\$ 3,000$, while commercial dumping is a misdemeanor offense resulting in a six-month jail sentence and up to a $\$ 10,000$ fine (Title 10 of Crimes against the Public Health and Safety, 1872).

Illegal dumping is hypothesized to be associated with an inability to afford proper disposal (Crofts, Morris, Wells, \& Powell, 2010; Ichinose \& Yamamoto, 2011; Karagiannidis, et al., 2005; Kim, Chang, \& Kelleher, 2008), disposal restrictions (Sigman, 1998), population density (Jorda-Borrell, Ruiz-Rodriguez, \& LucendoMonedero, 2014; Matos et al., 2012; Tasaki, et al., 2007), and inadequate enforcement 
(Crofts et al., 2010; Jorda-Borrell et al., 2014; Matsumoto \& Takeuchi, 2011). Previous studies have focused on economic, physical and demographic factors associated with illegal dumping. The causes of illegal dumping have yet to be explored from a social perspective which examines systemic drivers and issues of social justice.

\section{Literature Review}

Illegal dumping is a complex social, economic, and environmental issue which can most effectively be addressed through identification of its root causes. The theories of institutionalized racism and social disorganization help to explain the underlying causes of crime, including illegal dumping.

\section{Institutionalized Racism}

Despite the Civil Rights Movement and the implementation of the Civil Rights Act of 1964, minority populations are still denied a variety of privileges in the United States due to institutionalized racism (Rattansi, 2007). Racism itself can be both overt and covert (Carmichael \& Hamilton, 1967). Overt racism results in the destruction of property, death, or injury, and it can easily be observed (Carmichael \& Hamilton, 1967). Covert racism is not performed by a specific individual, but it is a product of societal institutions such as governments (Carmichael \& Hamilton, 1967). Institutionalized racism is a form of covert racism in which white individuals may not choose to act towards minorities overtly in a dangerous or threatening way, but do support institutions with racist laws or policies.

Due to institutionalized racism, minority populations of color have greater barriers to accessing high-paying jobs, quality schools, and healthy living environments, which has 
kept majority white populations in privileged positions (Delgado, Stefancic, \& Liendo, 2012). These barriers lead to poor educational attainment and health, unemployment, and unsafe neighborhoods with high rates of crime (Bullard, 1990; Cole \& Foster, 2001; Pellow, 2002; Rattansi, 2007). The social disorganization theory works to explain why some communities experience higher rates of crime than others.

\section{Social Disorganization Theory}

Increased rates of crime are often found in socially disorganized communities because of high rates of population turnover, cultural and racial heterogeneity, and poverty (Bursik \& Grasmick, 1993; Kubrin \& Weitzer, 2003; Sampson \& Raudenbush, 1999). Communities can be both socially and physically disorganized (Steenbeek \& Hipp, 2011). Social disorder occurs through activities such as public drinking, or verbal harassment, while physical disorder can be seen in illegally dumped garbage, litter, graffiti, abandoned vehicles, and drug paraphernalia (Sampson \& Raudenbush, 2004; Steenbeek \& Hipp, 2011).

Social disorganization theory assumes that communities can control and prevent the occurrence of crime through collective supervision (Bursik, 1988). Collective supervision includes informal surveillance of neighbors or other residents, avoiding unsafe areas, or confronting suspicious individuals (Bursik, 1988). Communities can self-correct when they have strong social networks that both establish and communicate norms of the community (Bursik, 1988). A socially disorganized community does not have the capacity to solve or prevent criminal issues that arise because of a lack of communication (Bursik, 1988). When a community is composed of renters, or individuals of varying 
cultural backgrounds, social connections are often non-existent or weak which leads to social disorganization and increased crime rates (Bursik, 1988). Low-income or minority individuals often live in the most deprived areas of cities, which lack adequate environmental health, municipal services, and social organization. The presence of illegal dumping is a contributor to physical disorganization within communities.

\section{Illegal Dumping}

What is illegal dumping? Illegal dumping is when waste such as construction and demolition debris, auto parts, scrap tires, appliances, household trash, yard waste, furniture, hazardous waste, or biomedical waste is deliberately disposed in non-permitted areas (United States Environmental Protection Agency, 1998). Illegal dumping can be carried out by households, businesses, and organized criminals (Matsumoto \& Takeuchi, 2011).

Effects of illegal dumping. Illegal dumping is known to cause negative environmental, health, and economic effects. Illegally dumped hazardous materials can contaminate soil and groundwater, cause flooding by blocking creeks and ravines, and negatively affect plants and wildlife (Critto, Carlon, \& Marcomini, 2003; United States Environmental Protection Agency, 1998). Critto et al. (2003) found that harmful pollutants from an illegal dump site in Venice, Italy percolated through the topsoil and

contaminated subsurface soil and nearby aquifers. The study concluded that humans and wildlife could be exposed to the harmful pollutants through direct inhalation of volatile contaminants, direct contact, or groundwater contamination.

Extensive studies have been completed on the effect of illegal dump sites and illegal 
burning of waste on human health in Campagna Italy's Triangle of Death (Comba, et al., 2006; Felice, et al., 2012; Giovannini, et al., 2014). Campagna residents have been exposed to harmful chemicals from illegally dumped waste through polluted soil and water, burned wastes, and consumption of foods farmed on contaminated soil (Felice, et al., 2012). Comba et al. (2006) found that residents living in areas surrounding illegal waste sites had increased rates of cancer mortality and congenital malformations. Felice et al. (2012) determined that pregnant women living in areas surrounding illegal landfills in Italy showed symptoms of premature aging (Felice, et al., 2012). Giovannini et al. (2014) detected high levels of dioxin in the breast milk of pregnant women near dump sites in the Naples and Caserta provinces of Campagna.

Illegal dumping also results in blight, which lowers real estate values, limits tourism, and compromises the safety of communities (Matos et al., 2012; Matsumoto \& Takeuchi, 2011; Webb et al., 2006). Illegal dump sites are difficult to remediate, and they can be a financial burden on municipalities (Matsumoto \& Takeuchi, 2011). In 2010, for example, Australian local governments spent $\$ 10$ million removing and disposing of illegally dumped wastes (Crofts et al., 2010). The United Kingdom spends an estimated $€ 100$ to $€ 150$ million ( $\$ 110$ to $\$ 170$ million) every year to find and clean illegal dump sites (Ichinose \& Yamamoto, 2011). Illegal dumping site remediation costs can consume as much as $30 \%$ of municipal government budgets in the United States (Glanville \& Chang, 2015).

Causes of illegal dumping. Illegal dumping is hypothesized to be associated with disposal costs (Crofts et al., 2010; Ichinose \& Yamamoto, 2011; Karagiannidis, et al., 
2005; Kim et al., 2008), fines (Crofts et al., 2010; Ichinose \& Yamamoto, 2011), disposal restrictions (Sigman, 1998), accessibility (Jorda-Borrell et al., 2014; Matos et al., 2012; Tasaki, et al., 2007), population density (Jorda-Borrell et al., 2014; Matos et al., 2012; Tasaki, et al., 2007), surveillance (Crofts et al., 2010; Jorda-Borrell et al., 2014; Matsumoto \& Takeuchi, 2011), unemployment (Matsumoto \& Takeuchi, 2011), and income (Jorda-Borrell et al., 2014; Karagiannidis, et al., 2005; Tasaki, et al., 2007).

Illegal dumping rates are known to intensify with increased legal waste disposal fees. A study completed in Japan by Ichinose and Yamamoto (2011) found that a smaller number of available waste processing facilities led to increased disposal rates and greater amounts of illegal dumping. Illegal dumping increases have been also associated with unit pricing. Unit pricing is when residents are charged by the bag or weight of garbage, rather than a flat rate for pick up and disposal service (Kim et al., 2008). Kim et al. (2008) found that a $1 \%$ increase in the unit price of a trash bag led to a $3 \%$ increase in the number of reported illegal dumping incidents in Korea.

Crofts et al. (2010) explored illegal dumping from a criminal perspective in Australia. These authors found that crimes are usually committed when the reward outweighs the costs. In the case of illegal dumping, legal waste disposal is costly, while illegal dumping is free (Crofts et al., 2010). Greater fines for illegal dumping may influence this behavior. Ichinose and Yamamoto (2011) found that increased penalties for illegal dumping decreased illegal dumping rates in Japan. Sigman (1998) found no relationship between the level of state penalties for the illegal disposal of oil and the frequency of illegal dumping, contrary to the findings of Ichinose and Yamamoto (2011). Policies regarding 
disposal restrictions may also influence illegal dumping behavior. A study completed by Sigman (1998) on the illegal disposal of oil within the United States found that state disposal restrictions on used oil led to a $28 \%$ increase in the frequency of illegal dumping.

Illegal dumping is more likely to occur in areas that are easily accessible by roads, with low population density and little surveillance. Matos et al. (2012) completed a study in Slovenia which quantified landscape features that attract illegal dumping. The study concluded that illegal dumping was found in areas with road access, low population density, and mountainous terrain (Matos et al., 2012). Tasaki et al. (2007) found that urban areas with a population density of 1,000 people per square kilometer had less illegal dump sites than rural areas with a density of 100 people per square kilometer. Tasaki et al. (2007) also found that many illegal dump sites occurred within $100 \mathrm{~m}$ of a road. Jorda-Borrell et al. (2014) found more illegal dumping within municipalities with high populations, but the illegal dump sites were more closely concentrated in rural areas with low visibility, and less than $500 \mathrm{~m}$ from a road. Crofts et al. (2010) highlight that increased surveillance, either informally by neighbors or other individuals or through technology such as cameras, can increase the offenders' perceptions that they will be caught, which deters crime. Matsumoto and Takeuchi (2011) found that patrolling by residents in specific neighborhoods measurably reduced the number of illegal dumping incidents of household electrical appliances.

Illegal dumping is influenced by both income and unemployment. Tasaki et al. (2004) found that illegal dump sites were more abundant in low-income areas of Japan while 
larger illegal dump sites were found in high income areas, likely due to lower population density. Matsumoto and Takeuchi (2011) found that Japanese citizens were more likely to dump electric appliances in areas of high unemployment. Karagiannidis et al. (2005) studied the effect of a unit pricing system on illegal dumping in Greece through resident surveys. The study found that low-income residents were more likely to dump illegally when they were expected to pay per amount disposed (Karagiannidis, et al., 2005). JordaBorrell et al. (2014) completed an illegal dump study comparing multiple cities in southern Spain and found that municipalities with high socioeconomic status had higher rates of illegal dumping.

\section{Problem Statement}

Illegal dumping is a problem facing countries all over the world including the Czech Republic (Kubasek \& Hrebicek, 2013), Japan (Ichinose \& Yamamoto, 2011; Matsumoto \& Takeuchi, 2011; Tasaki, et al., 2004), Australia (Crofts et al., 2010; Glanville \& Chang, 2015), Slovenia (Matos et al., 2012), Italy (Biotto, et al., 2009; Critto et al., 2003; Felice, et al., 2012; Giovannini, et al., 2014), Spain (Jorda-Borrell et al., 2014) and the United States (Fullerton, 1995; Kinnaman, 1996; Sigman, 1998; United States Environmental Protection Agency, 1998). Illegal dumping is known to cause many negative health, environmental, and economic effects (Comba, et al., 2006; Critto et al., 2003; Felice, et al., 2012; Giovannini, et al., 2014).

Although many authors have documented the apparent causes and effects of illegal dumping, researchers have yet to fully understand illegal dumping from a systemic perspective. This study examined the relationships between community demographic 
factors and dumping prevalence to evaluate whether the theory of social disorganization explains dumping within communities of San José, California.

\section{Research Objectives}

The main factors of social disorganization theory (racial heterogeneity, poverty, and population turnover) were examined in relation to dumping within census block groups of San José. This study also considered the relationship between illegal dumping and crime. Illegal dump sites were mapped and characterized to understand where illegal dumping occurred, and which types of debris were dumped.

\section{Research Questions and Hypotheses}

The following research questions and hypotheses were addressed:

Research Question 1: How do the types of illegally dumped items differ among census blocks of high, medium-high, medium-low, and low median family income of San José?

Hypothesis 1: Racial heterogeneity, income, and population turnover influence the total mass of dumped items within census block groups.

Hypothesis 2: The total mass of dumped items within a census block group predicts the occurrence of other instances of crime within census block groups.

\section{Methods}

\section{Study System}

This study was completed within the city of San José, which is located at the southern end of the San Francisco Bay in Santa Clara County, and the Santa Clara Valley (Figure 
1). San José is largely urban, with a population of $1,000,860$, designating it as the third largest city in California and the tenth largest city in the United States (United States Census Bureau, 2015). San José is bordered by the cities of Santa Clara, Saratoga, Campbell, Los Gatos, Morgan Hill, and Milpitas with a summed population of 319,828 (United States Census Bureau, 2015). The San José city limits sprawl over $467 \mathrm{~km}^{2}$ of largely urban areas (United States Census Bureau, 2015).

Despite a dominantly urbanized landscape, San José is located within an important and diverse ecological area. Six of the Santa Clara Valley watersheds drain via San José through $604 \mathrm{~km}$ of creeks and canals (Santa Clara Valley Water District, 2017). The western California coast which encompasses San José was designated as a biodiversity hot spot by Myers et al (2000) due to a high percentage of endemic plant and animal species.

San José is racially, ethnically, and culturally diverse. Asians comprise $33.5 \%$ of the city's population, Hispanics comprise $32.9 \%$, Whites 27\%, and Blacks $2.8 \%$ (United States Census Bureau, 2015). More than half of San José's population speaks a nonEnglish language at home (United States Census Bureau, 2015). A total of $43.4 \%$ of San José residents speak English, 23.6\% speak Spanish, and 25.5\% speak Asian/Pacific Islander languages (United States Census Bureau, 2015). 


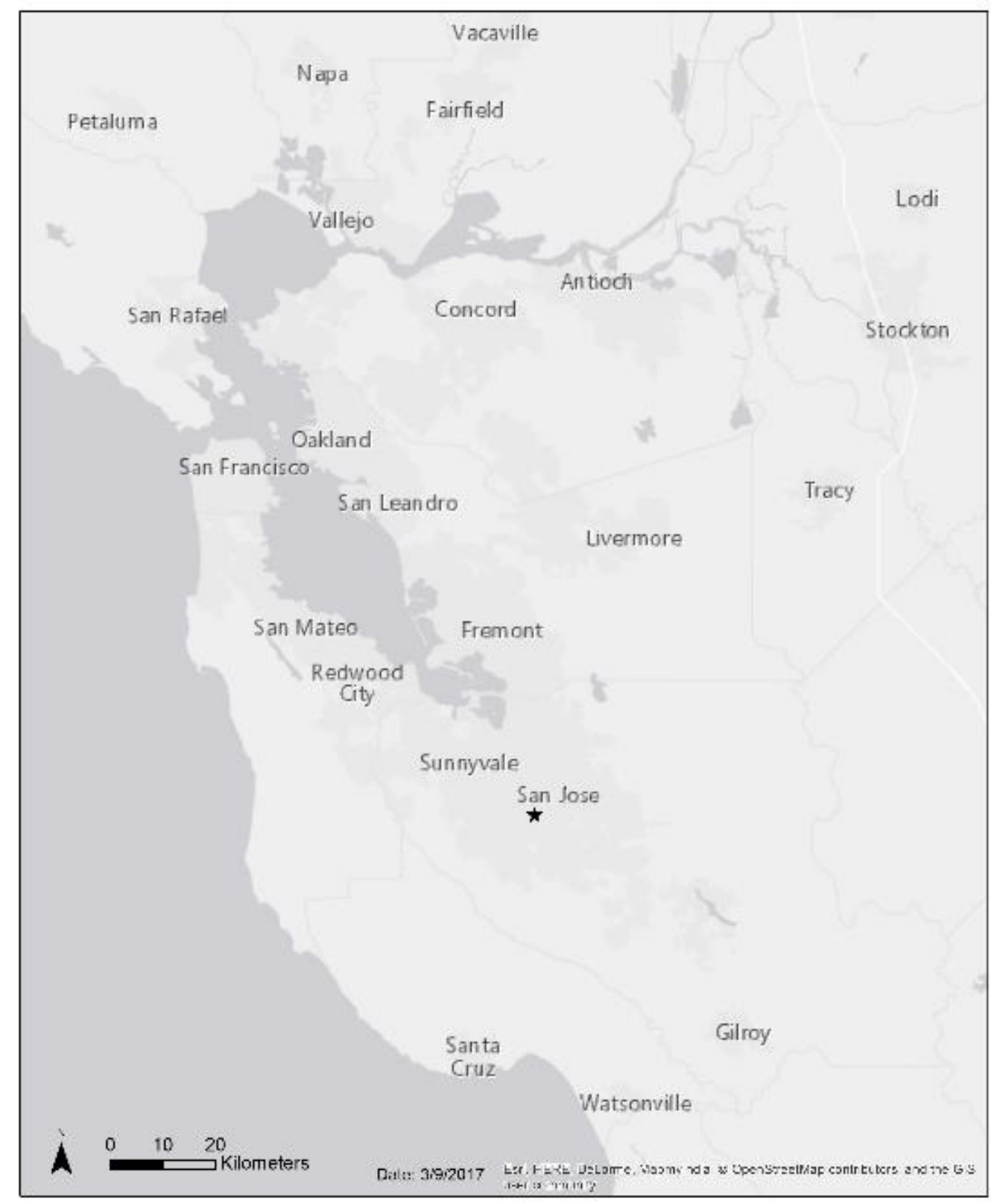

Figure 1: Map of the San Francisco Bay Area, from ESRI and Amory Brandt (2017).

The San Francisco Bay area is highly productive, with leading industries of science, and information technology. Major technology companies employ a little over 39,000 San José residents (United States Census Bureau, 2015). The presence of technology companies has led to income disparities, and high housing prices in the San Francisco 
Bay Area. The average rent for a one bedroom apartment in San José was \$2,026 in 2014 (City of San Jose, Q3 2014). Only 21\% of families in San José can afford a medianpriced home, compared to 63\% nationally (City of San Jose, Q3 2014). In San José, $42.7 \%$ of individuals rent their home, while $57.2 \%$ own compared to the national level of 67.1\% (United States Census Bureau 2010).

\section{Study Design}

This study analyzed physical and societal factors associated with illegal dumping in San José. All debris sampling for this study took place between November 12 and December 4, 2016. Primary data were collected on Saturdays, Sundays, and one Wednesday. In addition to primary data collected in the field, secondary illegal dumping photographs from GreenTeam of San José were used from November 12, November 19, and December 3, 2016.

Selecting census block groups. The unit of analysis for this study was the census block group. The block group was chosen because it is the smallest geographic area with publicly accessible data from the U.S. Census bureau. A total of forty block groups were sampled. Eligible census block groups for sampling included those that were located completely within the San José City limits, contained at least $2.4 \mathrm{~km}$ of street length, and were considered urban, with a population density greater than 1000 people per mile ${ }^{2}$ (386 people $/ \mathrm{km}^{2}$ ) as defined by the U.S. Census Bureau (Ratcliffe, Burd, Holder, \& Fields, 2016). Ineligible block groups were eliminated from the selection process, and the remaining block groups were split into four quartiles by median family income. Median family income was chosen because it was perceived to be a more accurate representation 
of income than median household income, as household sizes in San José are larger than the national average (United States Census Bureau, 2014). Forty block groups were selected from leveled income ranges to ensure adequate distribution of income levels within the sampled areas. The block groups were arranged by median family income from highest to lowest, then split into four quartiles. A random number was assigned to each of the block groups within the quartiles. Ten random numbers were generated for each quartile using Microsoft Excel. The block groups that matched the randomly generated numbers were sampled (Figure 2).

Limitations. This study only identified illegal dumping sites in urban areas of the San José which were accessible by paved roads. This study did not account for larger open dumps which may occur in rural areas, although previous research determined that illegal dumping is most likely to occur in areas with road access (Matos, Kristof and Ostir 2012). In addition, the sample size of this study was small and of limited duration, due to the labor-intensive data collection process. The small sample size allowed for few parametric tests. 


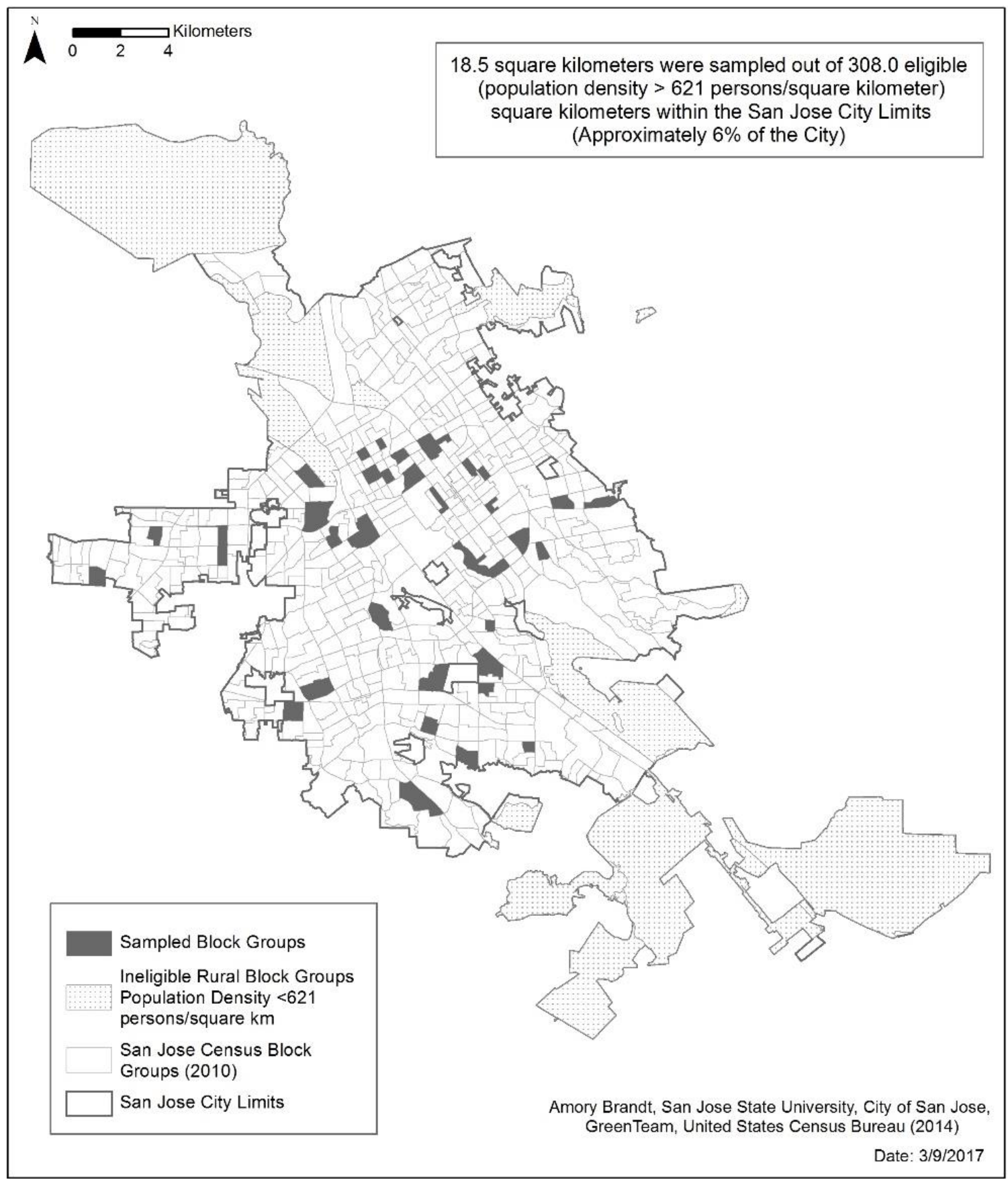

Figure 2. Forty census block groups were sampled within San José, California, from Amory Brandt, City of San Jose, United States Census Bureau (2017). 


\section{Data Collection}

Primary data collection. Debris sampling was timed to avoid neighborhood garbage and recycling pick-up days and large item pick-up set-outs. Field sampling occurred on Saturday, November 12, 2016 (11 block groups); Saturday, November 19, 2016 (16 block groups); Sunday, November 20, 2016 (7 block groups); Wednesday, November 23, 2016 (5 block groups); and Sunday, December 4, 2016 (1 block group). Saturday and Sunday sampling occurred between $10 \mathrm{AM}$ and 4 PM. The Wednesday sampling occurred between $2 \mathrm{PM}$ and $5 \mathrm{PM}$.

Identification of illegal dump sites. Illegally dumped debris was identified within the sampled census block groups by driving on all public streets within the block group, and taking geo-tagged photographs of each dump site. Illegally dumped debris was designated as any object larger than 0.5 square meters that was not located within a designated waste disposal bin (Figure 3).

Objects greater than one meter apart were photographed separately to represent two sites. Only items visible from the public right of way, and on public property were sampled. Photos were taken using smart phones of varying brands and models, but all contained global positioning satellite technology.

Secondary data. GreenTeam of San José cleans up and disposes of illegally dumped debris on Saturdays between 6 AM and 3 PM. GreenTeam takes geo-tagged photographs of all the sites they clean. Photos from GreenTeam of San José were utilized for three Saturdays: November 12, November 19, and December 3, 2016. 


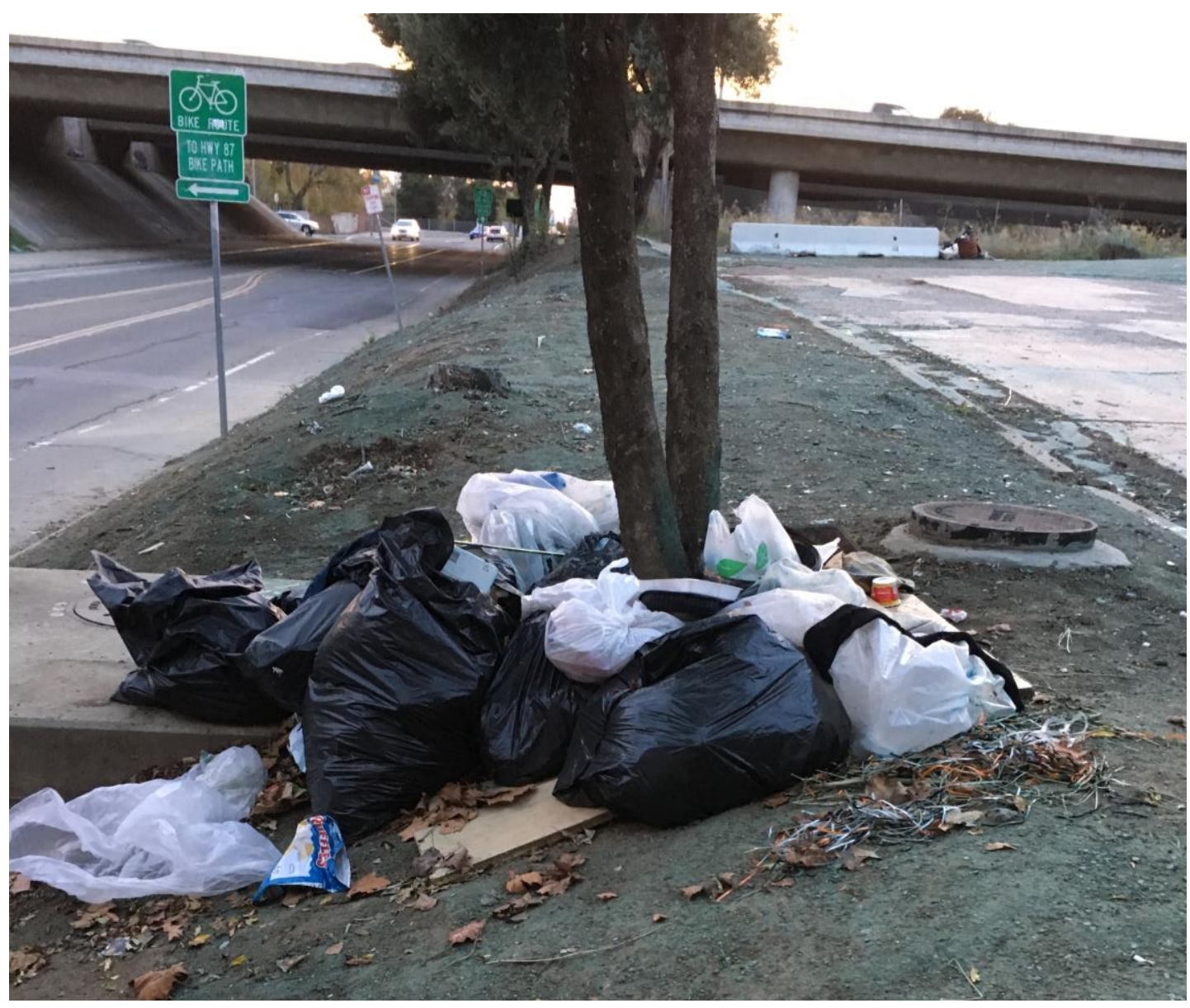

Figure 3. Example photograph of single illegal dump site.

Demographic data. All demographic data were obtained from the United States

Census Bureau's 2014 American Community Survey using the American Fact Finder's data download center (United States Census Bureau, 2014). Demographic data included the number non-English speaking residents, median family income, and total number of renters per census block group in Santa Clara County.

Crime data. Crime data from November 7, 2016 to December 4, 2016 were retrieved from the City of San José online Data Download Center (City of San Jose, 2017). 
Geographic information systems data. Shapefiles for geographic information systems analysis were obtained from the City of San José, and United States Census Bureau. The San José City Limits and divided street segments in San José were downloaded from the City of San José's online Data Download center (2017). Shapefiles containing the United States Census Block group boundaries were downloaded from the United States Census Bureau's TIGER/Line ${ }^{\circledR}$ Shapefiles website (2012).

\section{Data Analysis}

Photo processing. Before mapping, each photo was named with the date it was taken, its source (primary, or GreenTeam) and a unique sequential number. All illegal dump sites were mapped using the Environmental Systems Research Institute's ArcGIS, ArcMap 10.4.1 geographic information systems software. The photographs were mapped using the Photos to Points tool within ArcMap, which creates a shapefile containing the location of the photo using its embedded geographic coordinates. All sites were projected into the NAD_1983_StatePlane_California_III_FIPS_0403_Feet projection system. The sites located within the sampled census block groups for each data source were then isolated using the clip feature in ArcMap. Once the sites located within the census block groups were identified, the site locations were exported to a Microsoft Excel 2016 (C) 2016 Microsoft Corporation) spreadsheet using the Table to Excel tool in ArcGIS. The three sets of data were kept in separate spreadsheets for characterization.

To assess the types and quantity of debris at each site, each photo was analyzed separately for the types of debris it contained. For all data sets, the debris types and quantities were entered in Microsoft Excel, then the number of items was multiplied by 
an estimated mass in kilograms of each item using the Environmental Protection Agency's (EPA) (2016) volume-to-weight (mass) conversion factors (United States Environmental Protection Agency, 2016).

Once the illegal dumping site masses were calculated, each set of data was mapped in ArcMap using the Coordinates to Points tool. The sites were then spatially joined to the sampled census block groups, and the total kilograms of debris at each site were summed to determine a total mass of waste in kilograms for each census block group. The data were then exported again to Microsoft Excel using the Table to Excel tool in ArcMap. Before analysis, the total mass of debris recorded in each block group was divided by the total street length to account for different sized block groups.

Research question 1. To characterize the types of debris present within each income category, the primary data and GreenTeam data were used. The specific block group in which each site was located was determined using a Spatial Join in ArcGIS. The site locations, debris type, quantity, and total weight in kilograms were exported to Microsoft Excel from ArcGIS using the Table to Excel tool. Once in Excel, each site was identified with one of the four income categories described above. The total mass in kilograms of each debris category was then added together within each income level. The percentage of the debris type was calculated by dividing the mass for each debris type by the summed mass of all the debris within each income level. To determine the percent occurrence of each type of debris throughout all sampled block groups, the total mass of each debris type was added together across all block groups.

Hypothesis 1. To analyze the factors associated with the Social Disorganization 
theory, percent non-English speaking was used to represent population heterogeneity or diversity, while median family income represented income, and percent renters represented population turnover. Percentages were calculated by dividing the total amount for each category over the total number sampled by the Census Bureau.

The finalized Excel spreadsheet was imported into IBM SPSS Statistics 24.0. Using IBM SPSS, all demographic data containing percentages were angularly transformed. The data were checked for normality using the Shapiro-Wilk test, and only normal data were used for parametric analyses. A simple linear regression was completed to test the relationship between total mass of dumped debris within census block groups and percent renters, percent non-English speaking, and median family income. All independent variables that had a significant linear relationship with mass of dumped debris were then tested for intercorrelation and a multiple linear regression was completed incorporating uncorrelated predictors.

Hypothesis 2. Crime data were geocoded using the ArcGIS world geocoding service, then clipped to select the crime sites that occurred within the sampled block groups. The clipped data included crime instances from the following categories: abandoned vehicle, assault, battery, burglary, disturbance, felony hit and run, felony want, firearms discharged, malicious mischief, mentally disturbed person, misdemeanor dui, misdemeanor hit and run, misdemeanor want, narcotics, person down, reckless driving, recovered stolen vehicle, speed contest, stolen vehicle, suspicious circumstances, suspicious person, suspicious vehicle, trespassing, and unlicensed driver. The crime locations were spatially joined to the sampled block groups using ArcGIS to count the 
number of crime sites per block group. The illegal dump mass, and crime sites were standardized by the total street length $(\mathrm{km})$ in each block group and transformed for normality. A linear regression was completed in IBM SPSS with the mass of debris per $\mathrm{km}$ as the independent variable and the crime sites per $\mathrm{km}$ as the dependent variable.

\section{Results}

Income quartiles using leveled 2014 adjusted median family incomes yielded 10 block groups in each of the following categories: high $(\$ 113,438$ - $\$ 172,500)$, mediumhigh $(\$ 86,500-\$ 112,045)$, medium-low $(\$ 61,875-76,848)$, and low $(\$ 17,458-\$ 59,954)$ (Figure 4).

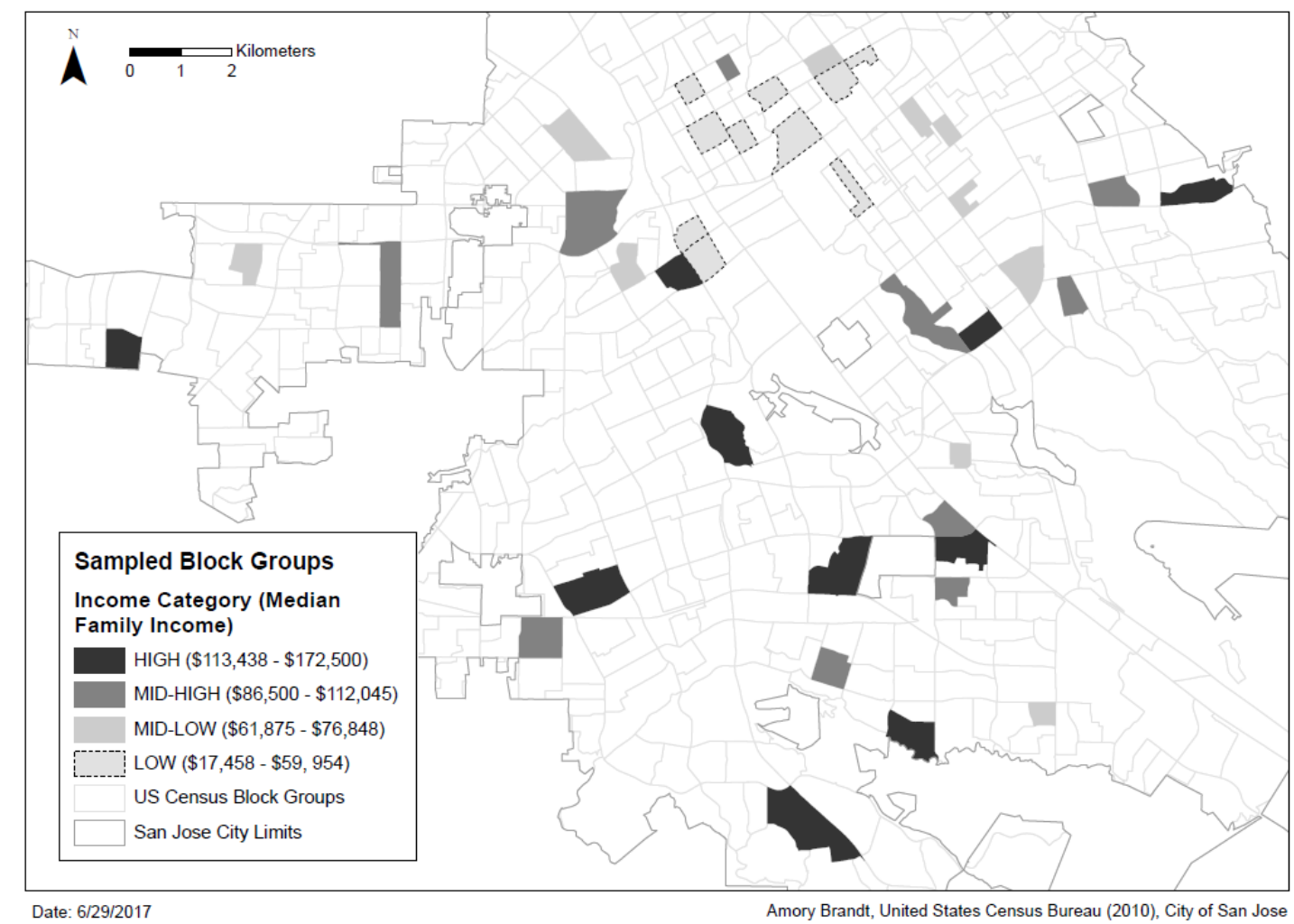

Figure 4: Sampled census block groups by median family income, San José, California, 2016, from Amory Brandt, United States Census Bureau, City of San Jose (2017). 


\section{Research Question 1}

The most commonly dumped debris type was furniture, which comprised $25 \%$ of all illegally dumped debris (Figure 5). The next most common debris type was garbage bags which comprised $12 \%$ of all illegally dumped debris, followed by appliances and mattresses at $11 \%$ and $9 \%$ respectively (Figure 5). Yard trimmings comprised 7\%, wood scraps $6 \%$, mixed textiles (pillows, blankets, clothing) 5\%, car/auto parts 5\%, scrap metal $4 \%$, electronics 3\%, and construction and demolition debris 3\% (Figure 5).

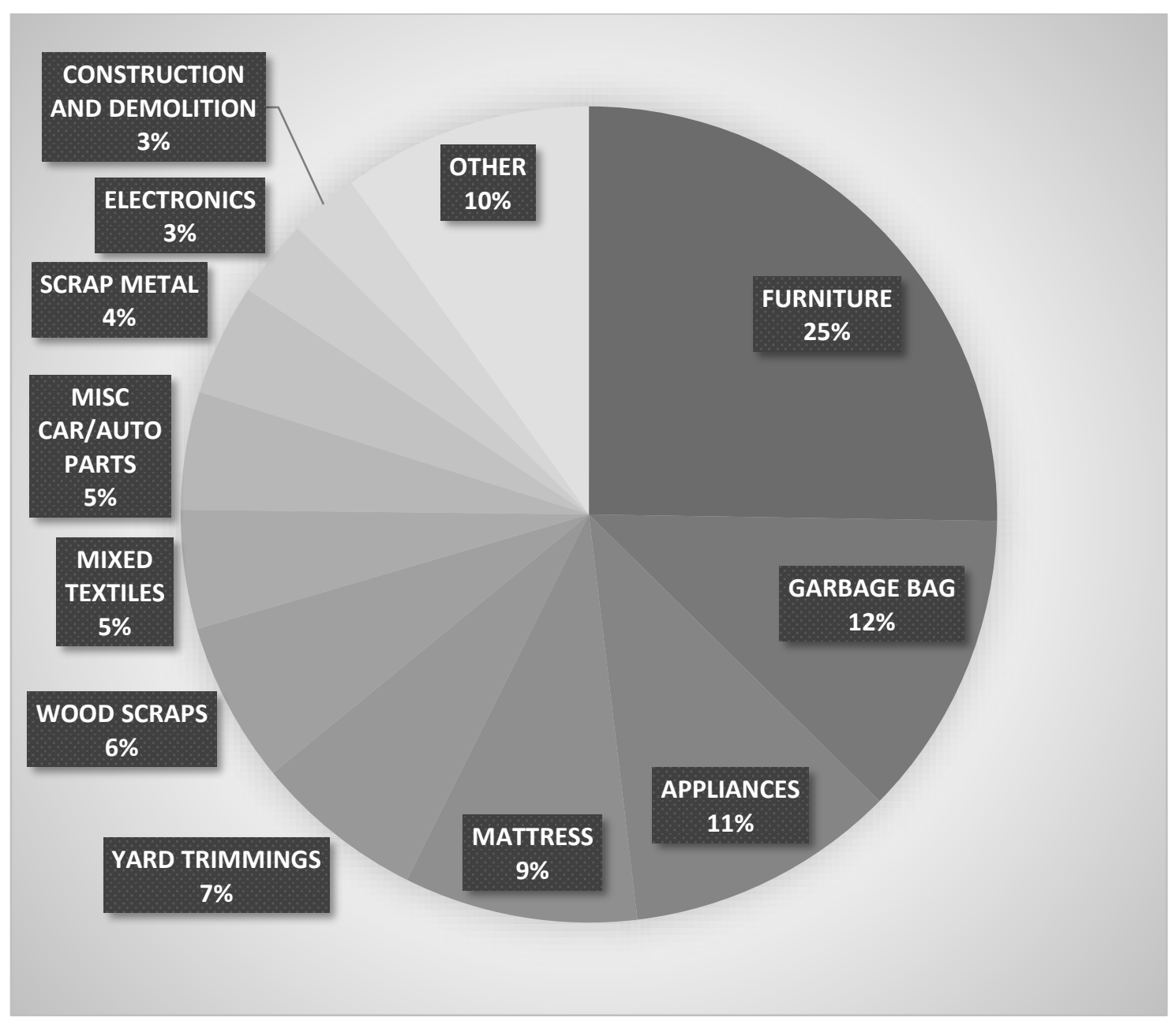

Figure 5. Percent composition of debris dumped throughout all sampled block groups 
All other debris types (child/baby/elderly items, homeless related debris, tires, exercise equipment, mixed ridged plastics, mixed recyclables, recreational vehicle related debris, patio/garden debris, hazardous waste, and polystyrene) comprised $10 \%$ of the debris altogether (Table 1).

Table 1

Composition of Other Debris Types Measured Between all Sampled Block Groups

\begin{tabular}{lll}
\hline Debris Type & Mass (kg) & Percent \\
\hline Child/Baby/Elderly Items & 14.11 & $1.66 \%$ \\
Homeless Encampment & 12.89 & $1.52 \%$ \\
Tire & 11.46 & $1.35 \%$ \\
Exercise Equipment & 11.44 & $1.35 \%$ \\
Mixed Rigid Plastics & 10.52 & $1.24 \%$ \\
Mixed Recyclables & 9.93 & $1.17 \%$ \\
RV/Mobile Home & 8.25 & $0.97 \%$ \\
Patio/Garden/Pool & 4.10 & $0.48 \%$ \\
Hazardous Waste & 1.34 & $0.16 \%$ \\
Polystyrene & 0.05 & $0.01 \%$ \\
\hline
\end{tabular}

The type of debris dumped varied by income category. The top five most commonly dumped debris types (furniture, garbage, appliances, mattresses, yard trimmings) were examined separately by income category. Furniture was most commonly dumped in midlow-income block groups at $45 \%$, and next most commonly in the low-income block groups at 35\% (Figure 6). 


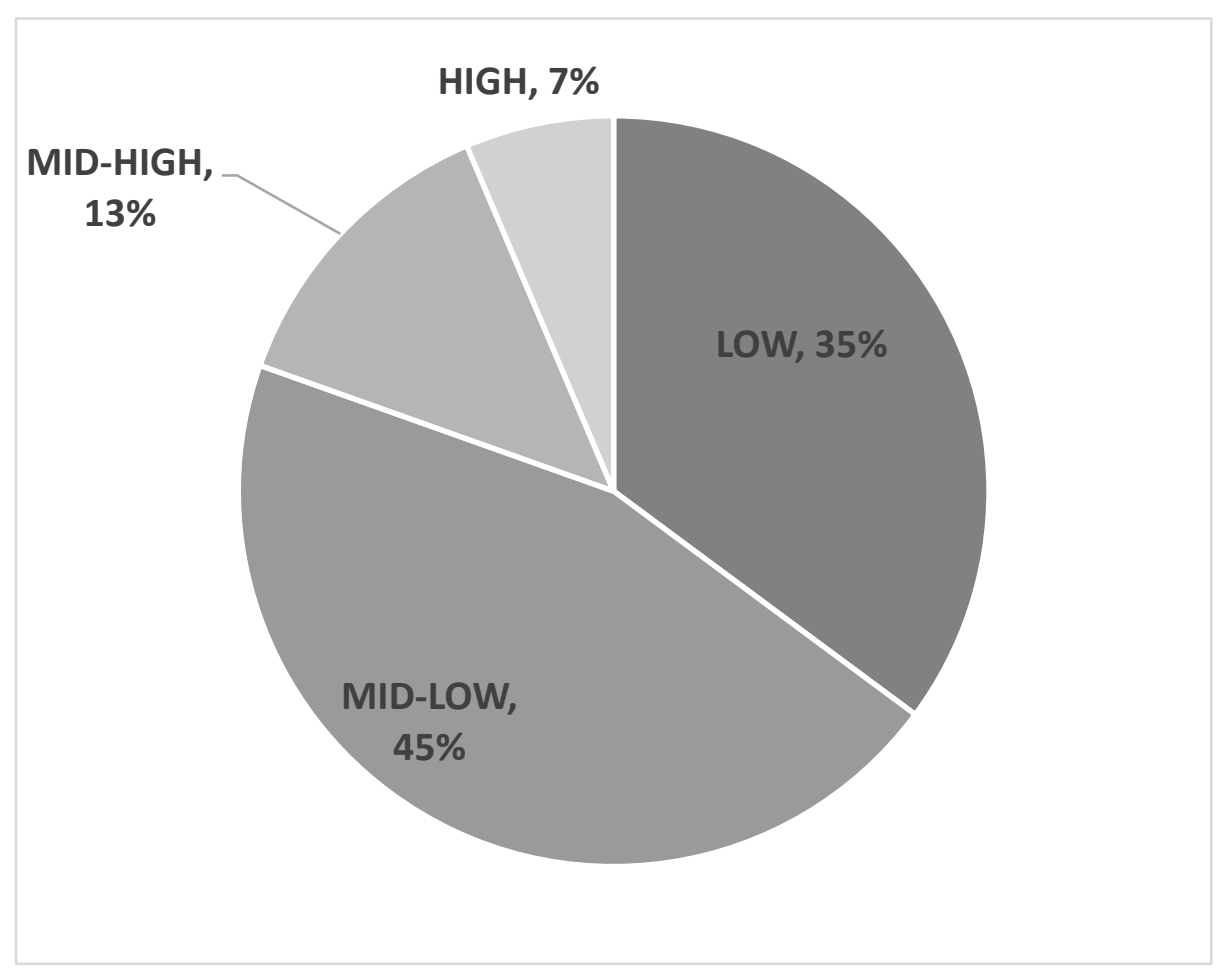

Figure 6. Distribution of illegally dumped furniture by income category.

Garbage was most commonly dumped in low-income block groups at 58\%, and next in mid-low-income block groups at 19\% (Figure 7). Small appliances were most commonly dumped within low-income block groups at $47 \%$, and next most commonly dumped in mid-low block groups at 20\% (Figure 8). Large appliances were most commonly dumped within low-income block groups at $45 \%$, then mid-low-income block groups at 26\%, and mid-high income block groups at 20\% (Figure 9). 


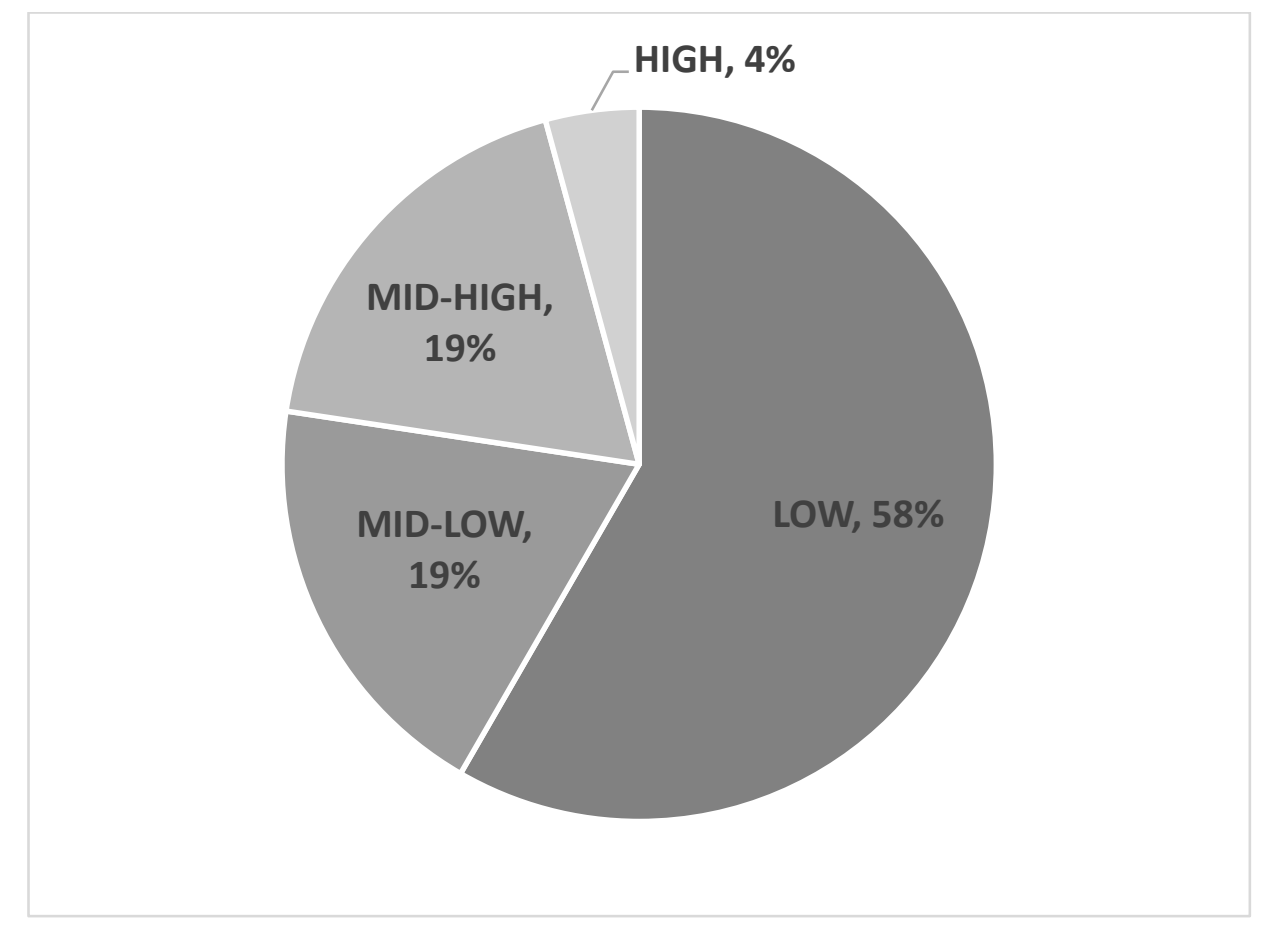

Figure 7. Distribution of illegally dumped garbage bags by income category.

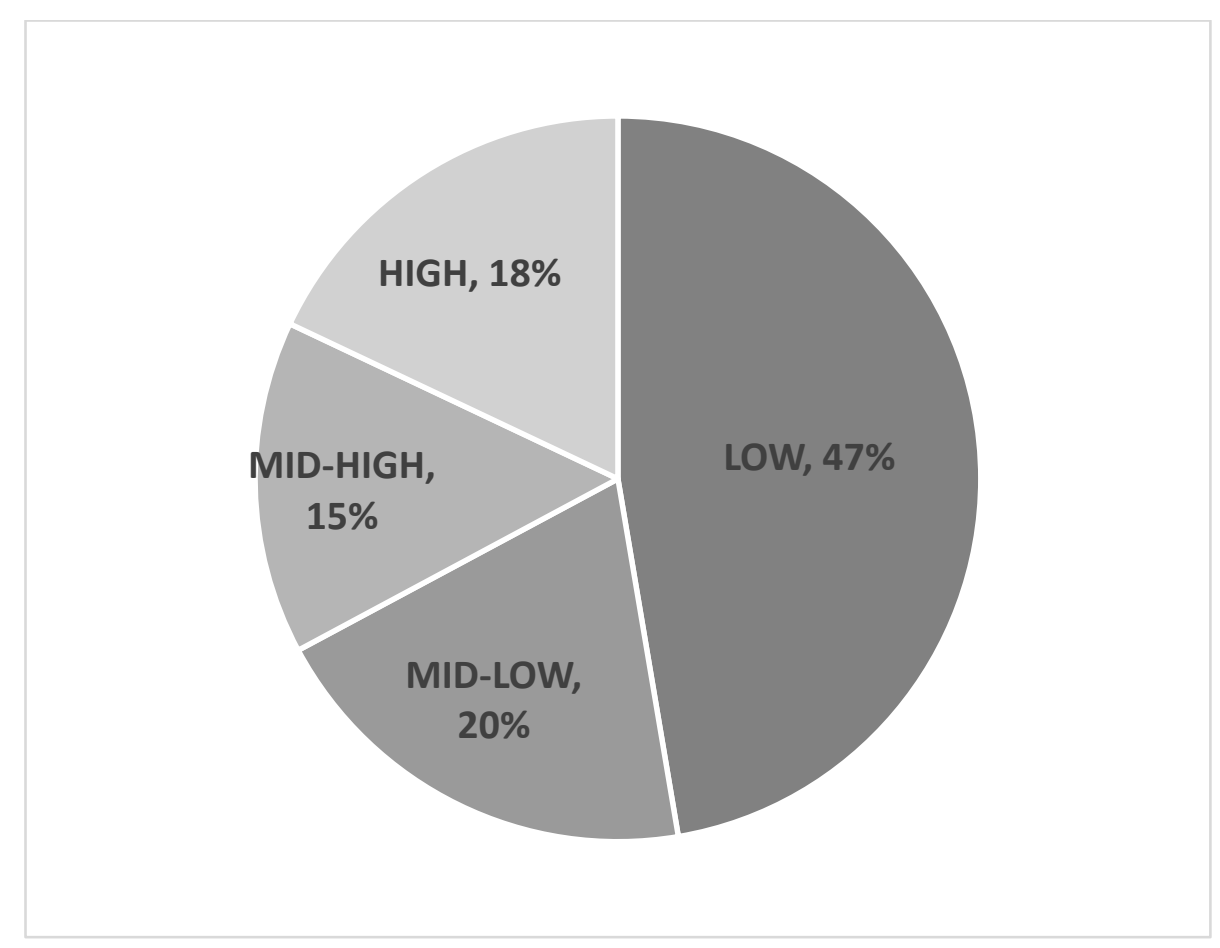

Figure 8. Distribution of illegally dumped small appliances (vacuum, microwave, toaster oven) by income category. 


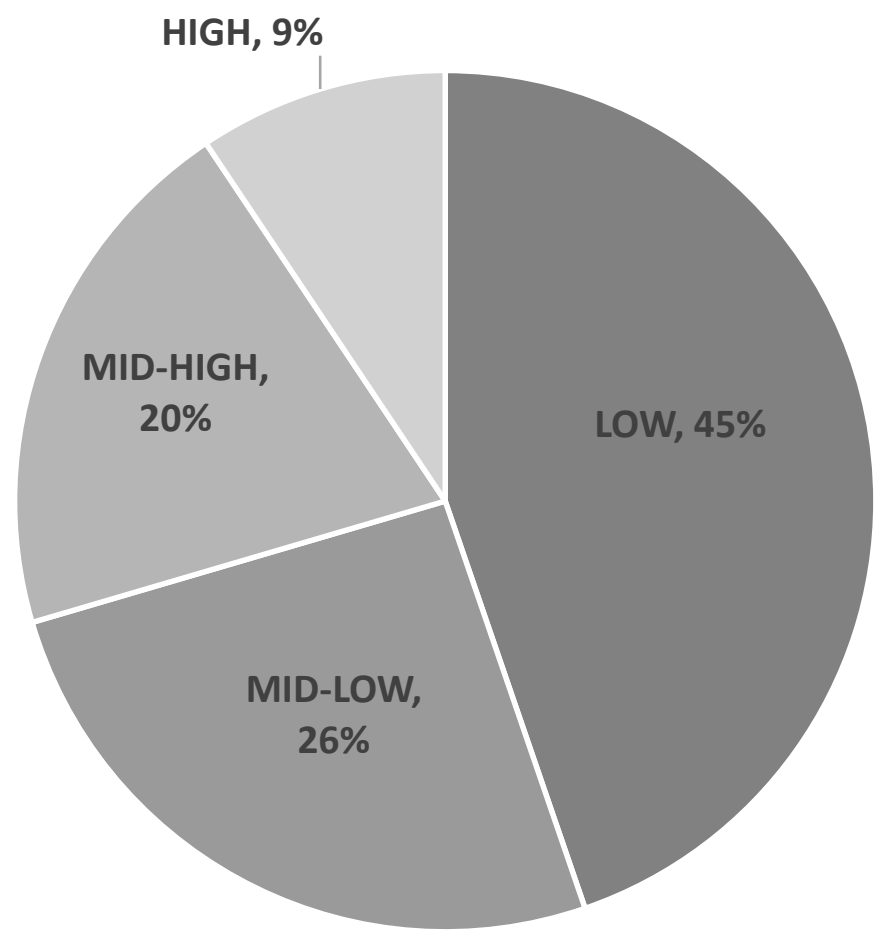

Figure 9. Distribution of illegally dumped large appliances (refrigerator, oven/stove, dishwasher) by income category.

Most mattresses were dumped within mid-low-income block groups at 53\%, then low-income at 36\% (Figure 10). Most yard trimmings were dumped illegally within lowincome block groups at 59\%, then in mid-low-income block groups at $41 \%$ (Figure 11). Electronics were most commonly dumped within low-income block groups at $74 \%$ (Figure 12). 


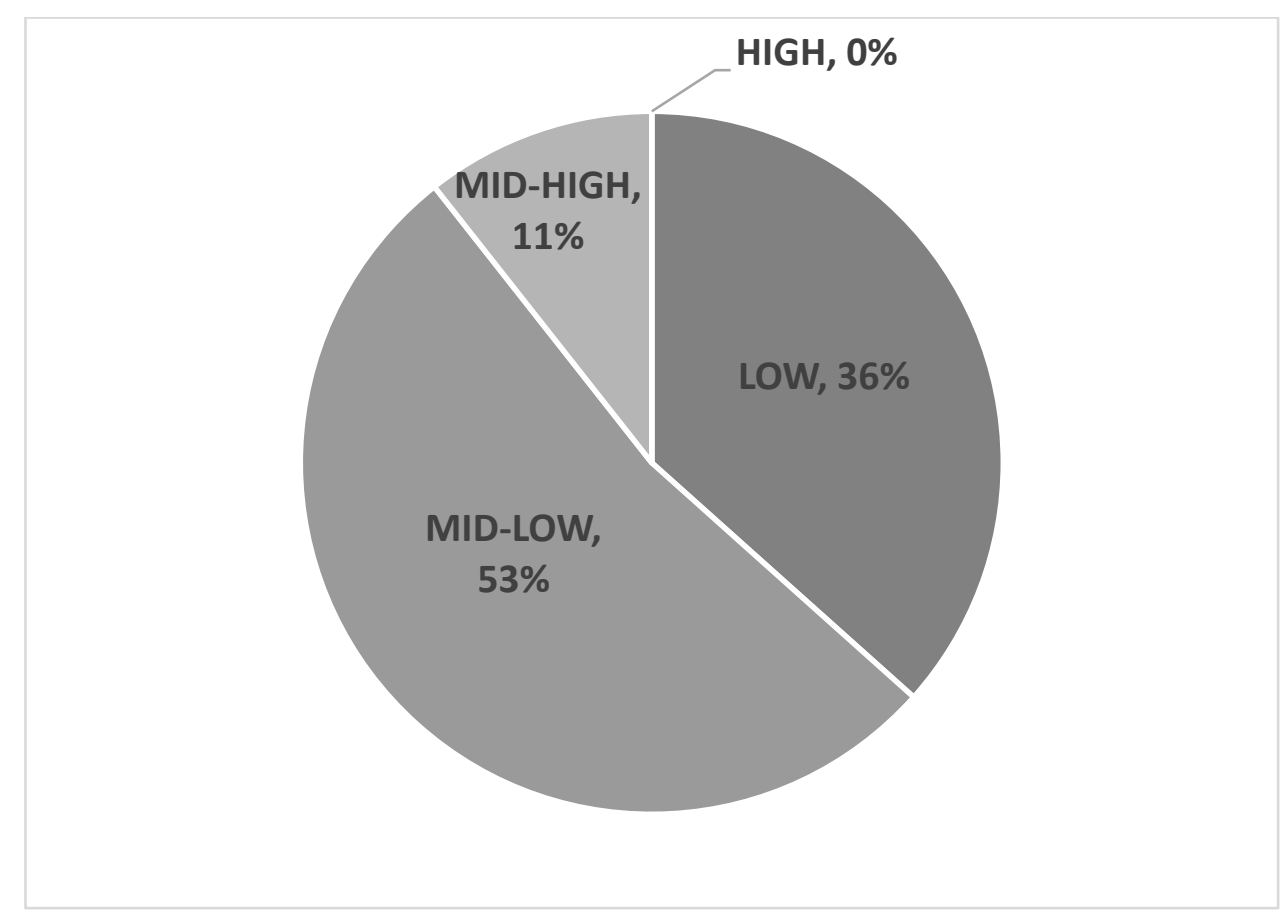

Figure 10. Distribution of illegally dumped mattresses by income category.

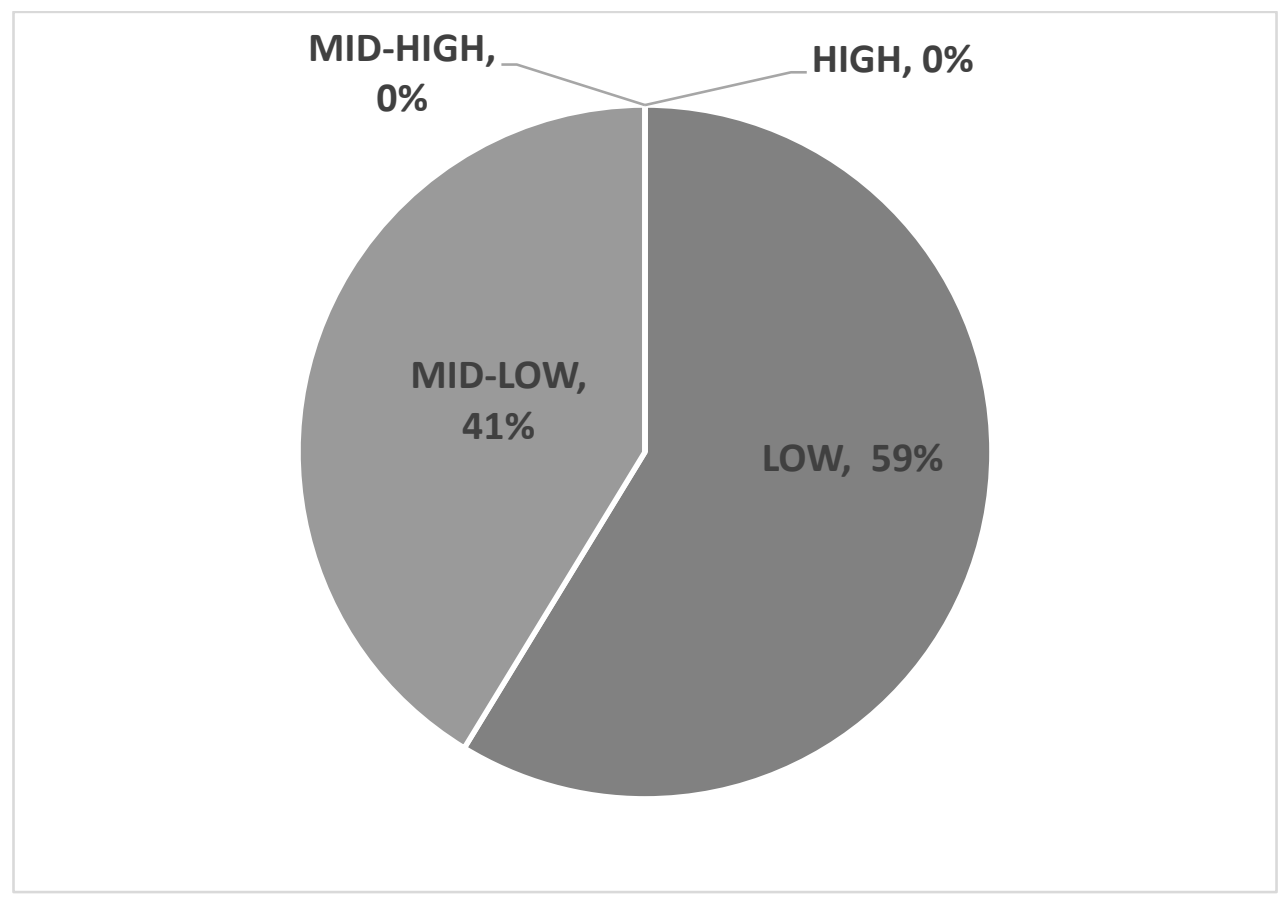

Figure 11. Distribution of illegally dumped yard trimmings by income category. 


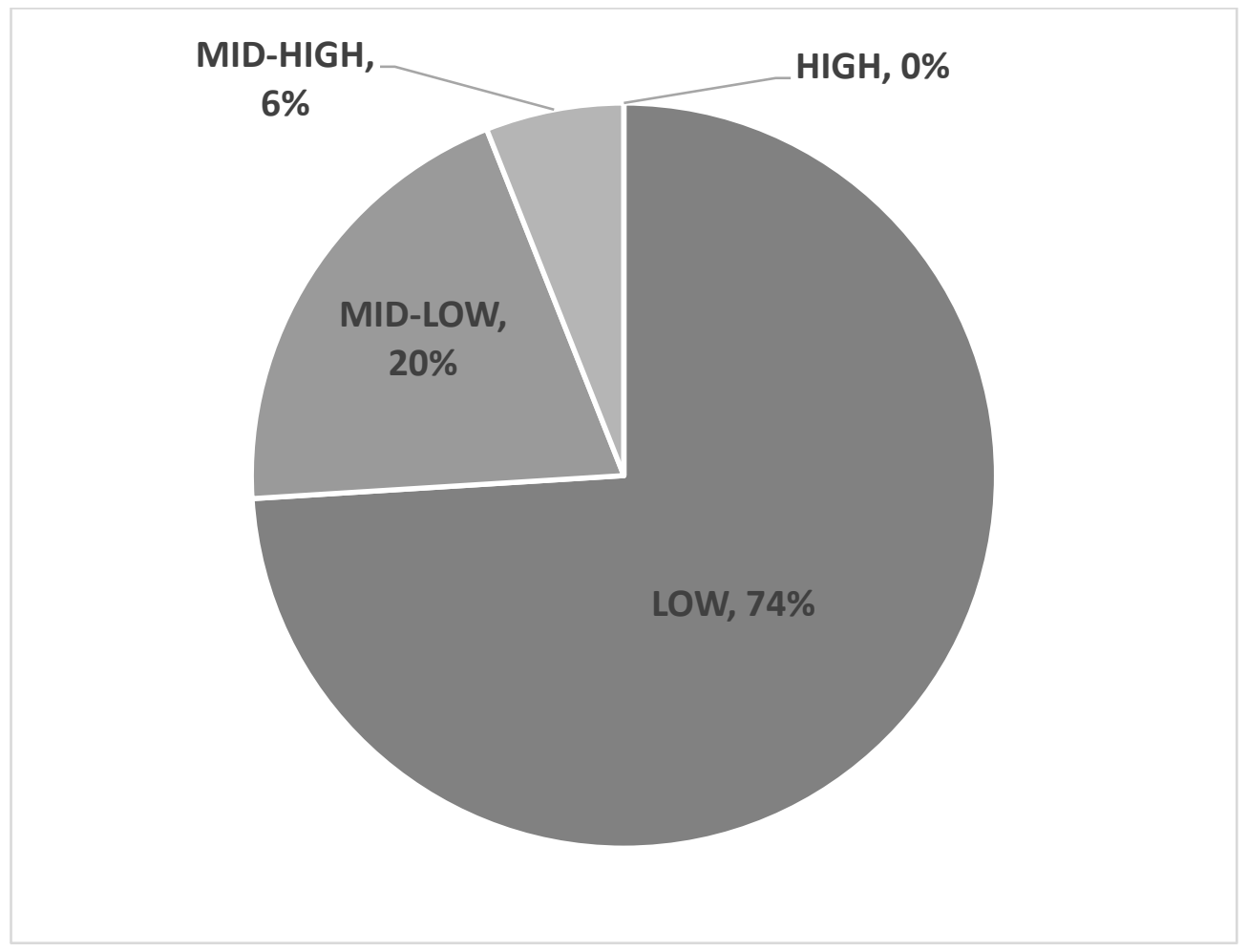

Figure 12. Distribution of illegally dumped electronics by income category.

\section{Hypothesis 1}

Mass of dumped debris decreased significantly with increasing median family income, adjusted $\mathrm{R}^{2}=0.366, \mathrm{~F}(1,38)=25.535, \mathrm{p}<0.001$ (Figure 13). Similarly, mass of dumped debris increased with increasing percent renters, adjusted $\mathrm{R}^{2}=0.161, \mathrm{~F}(1,37)=$ 8.315, $\mathrm{p}=0.007$ (Figure 14) and percent non-English-speaking individuals, adjusted $\mathrm{R}^{2}=$ $0.325, \mathrm{~F}(1,38)=19.779, \mathrm{p}<0.001$ (Figure 15).

All independent variables tested in the simple linear regressions were correlated with each other, except percent renters and percent non-English speaking residents (Table 2). The multiple linear regression including percent renters and percent non-English speaking versus $\mathrm{kg} / \mathrm{km}$ of dumping revealed significant positive relationships with both 
predictors, adjusted $\mathrm{R}^{2}=0.458, \mathrm{~F}=(2,36), 15.214, \mathrm{p}<0.001$. The $\mathrm{p}$ value for percent renters was 0.022 while the $p$ value for percent non-English speaking was $<0.001$.

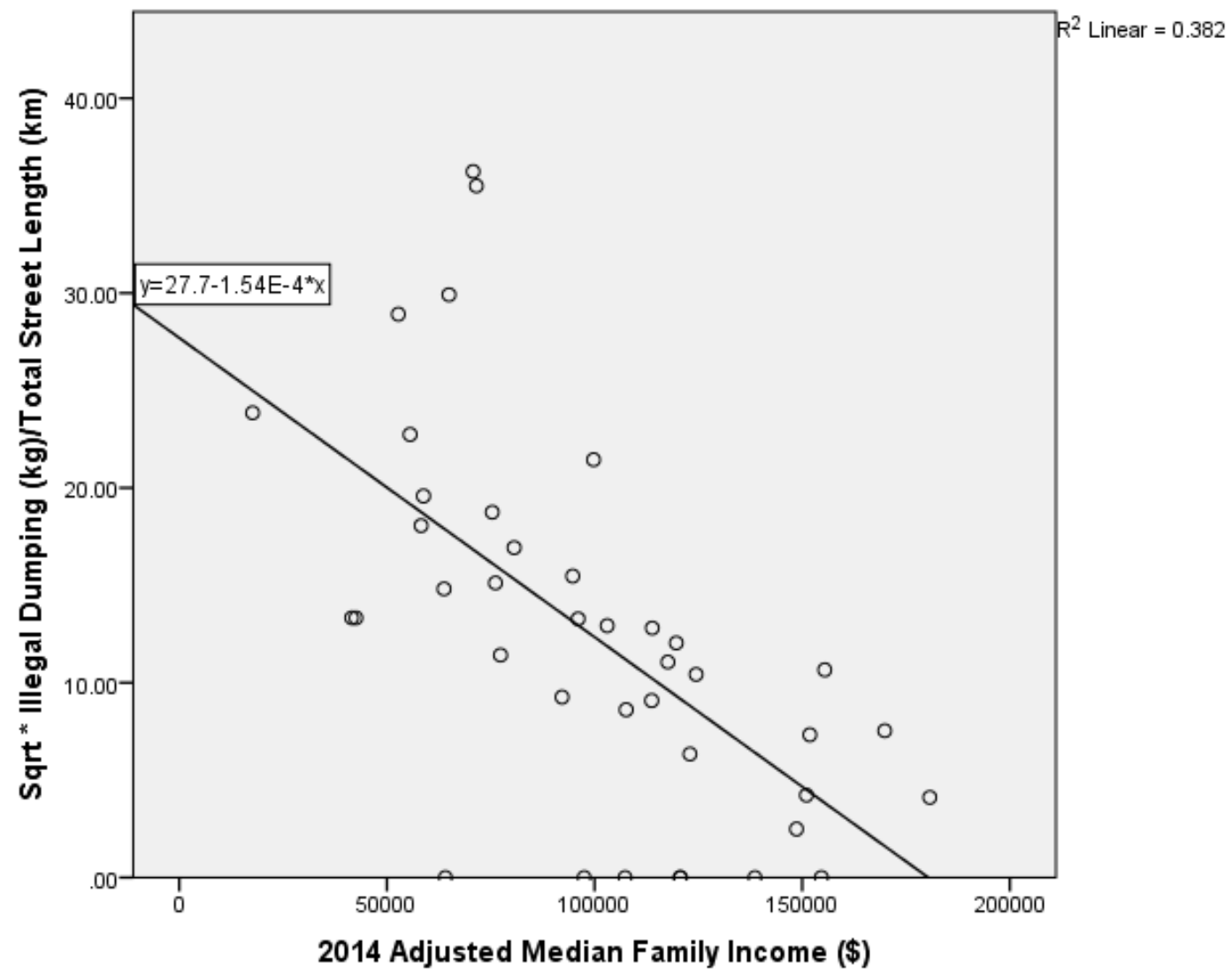

Figure 13. Mass of illegally dumped debris versus median family income. 


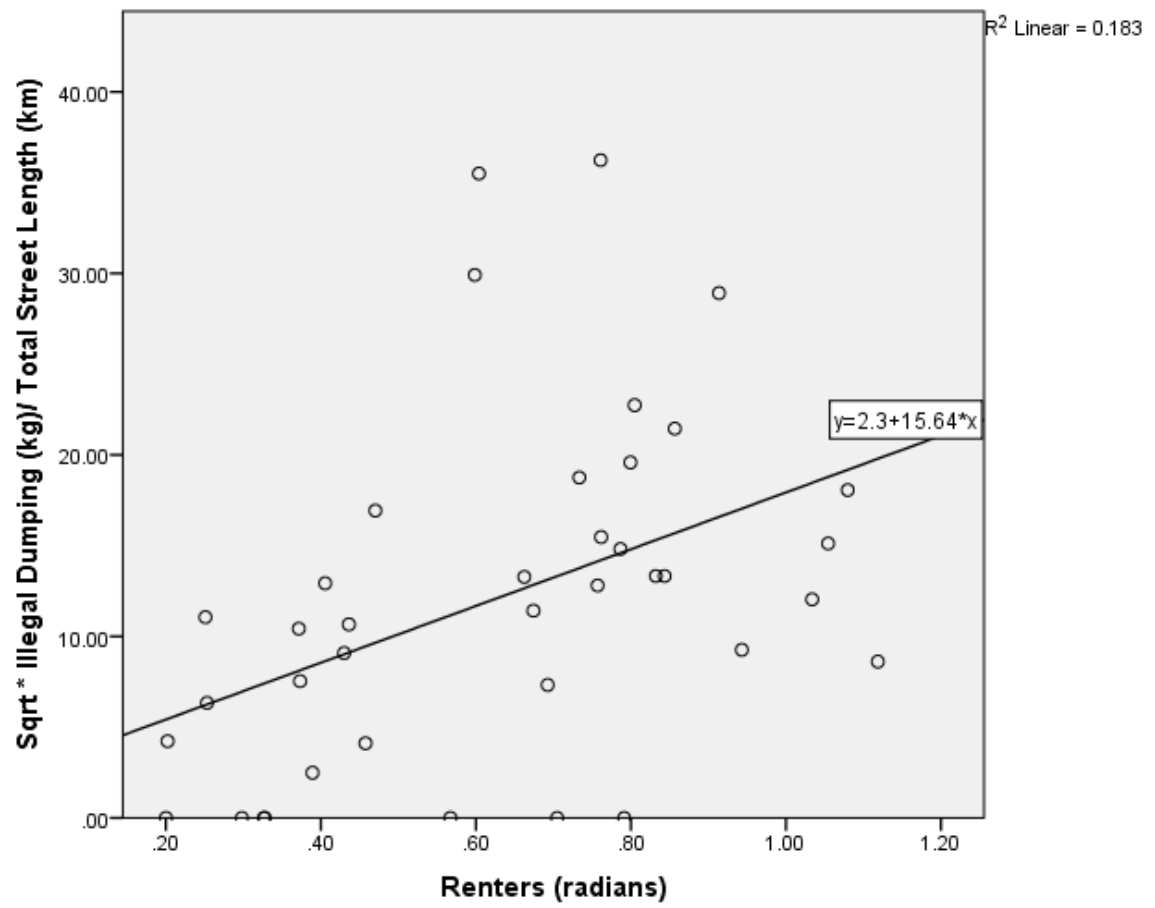

Figure 14. Mass of illegally dumped debris versus percent renters.

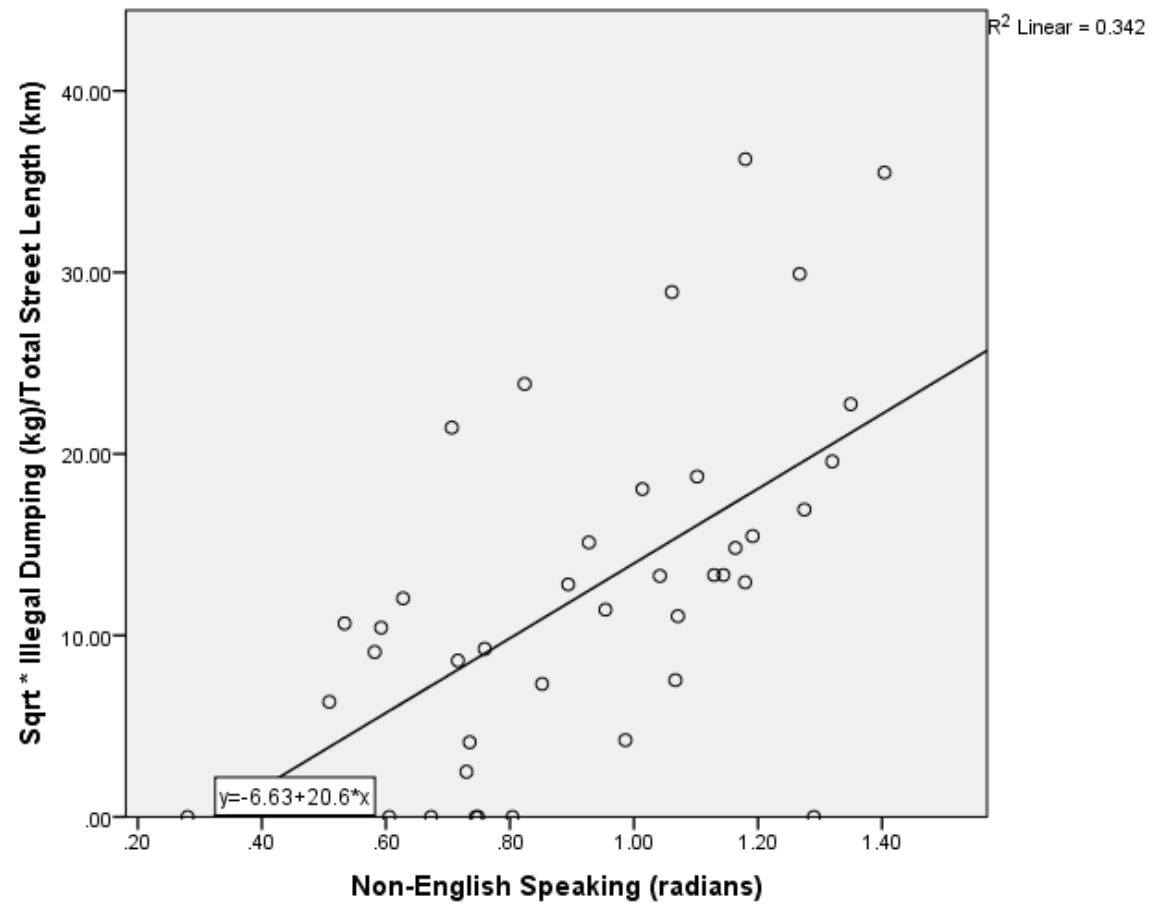

Figure 15. Mass of illegally dumped debris versus non-English speaking residents. 
Table 2

Correlations Between Median Family Income, Percent Renters, and Percent Non-English Speaking Residents

\begin{tabular}{|c|c|c|c|c|}
\hline & & $\begin{array}{c}\text { Median Family } \\
\text { Income }\end{array}$ & $\begin{array}{l}\text { Percent } \\
\text { Renters }\end{array}$ & $\begin{array}{c}\text { Percent Non- } \\
\text { English Speaking }\end{array}$ \\
\hline \multirow{3}{*}{$\begin{array}{l}\text { Median } \\
\text { Family } \\
\text { Income }\end{array}$} & Pearson Correlation & 1 & -0.561 & -0.592 \\
\hline & Sig (2-tailed) & & 0.000 & 0.000 \\
\hline & $\mathrm{N}$ & 40 & 39 & 40 \\
\hline \multirow{3}{*}{$\begin{array}{l}\text { Percent } \\
\text { Renters }\end{array}$} & Pearson Correlation & -0.561 & 1 & 0.232 \\
\hline & Sig (2-tailed) & 0.000 & & 0.155 \\
\hline & $\mathrm{N}$ & 39 & 39 & 39 \\
\hline \multirow{3}{*}{$\begin{array}{l}\text { Percent Non- } \\
\text { English } \\
\text { Speaking } \\
\end{array}$} & Pearson Correlation & -0.592 & 0.232 & 1 \\
\hline & Sig (2-tailed) & 0.000 & 0.155 & \\
\hline & $\mathrm{N}$ & 40 & 39 & 40 \\
\hline
\end{tabular}

\section{Hypothesis 2}

Crime sites per block group increased with mass of dumped debris/km/block group, adjusted $\mathrm{R}^{2}=0.260, \mathrm{~F}(1,38)=1,14.718 \mathrm{p}<0.001$ (Figure 16). 


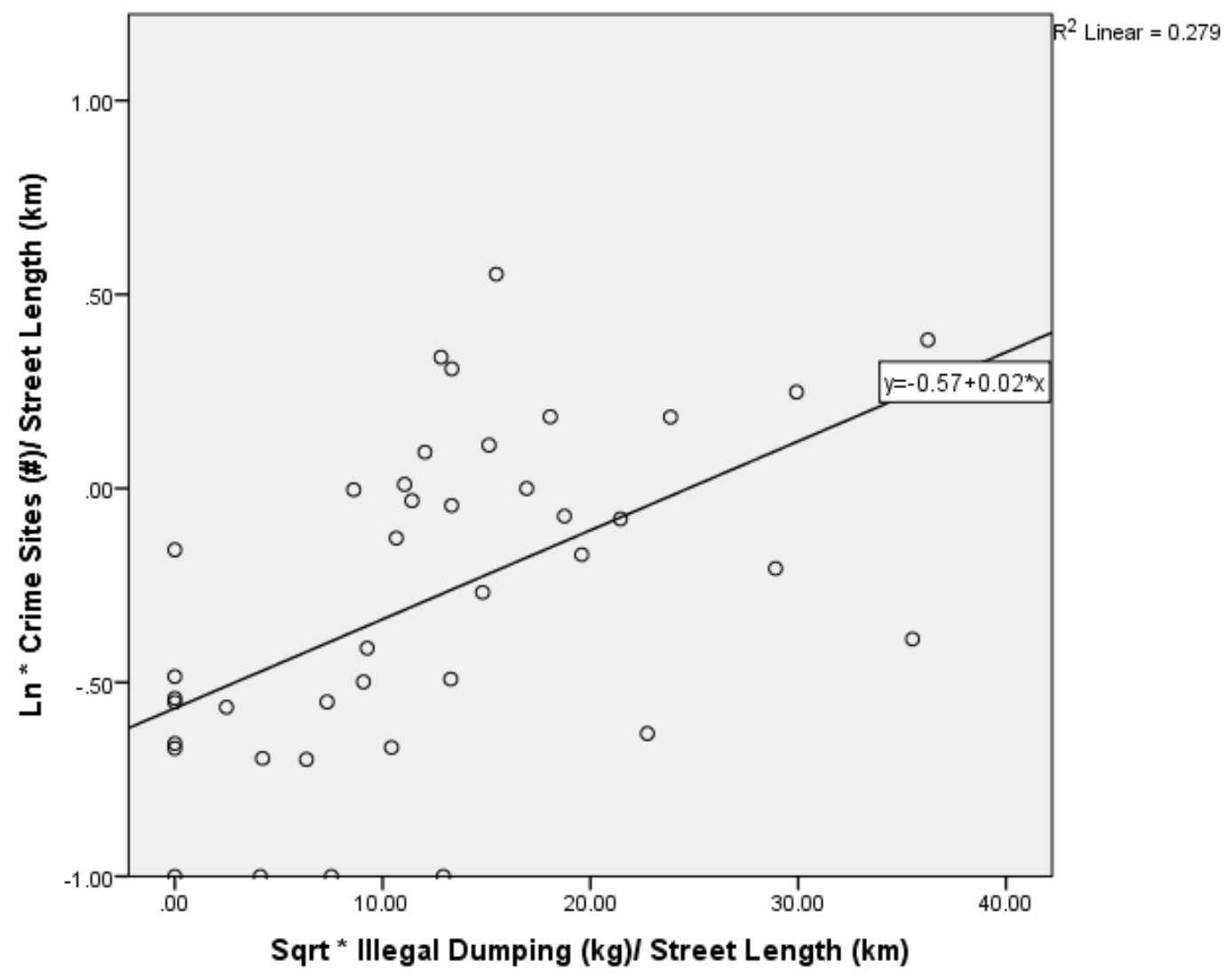

Figure 16. Illegal dumping compared to occurrences of crime within block groups

\section{Discussion}

\section{Furniture and Garbage Were Most Commonly Dumped}

The top two most common illegally dumped items were furniture and garbage bags.

Furniture was the most commonly dumped item by over $13 \%$. This was expected because furniture does not fit into normal garbage and recycling containers, and is heavy and bulky which makes it difficult to move. The City of San José offers a free "junk" pick up program that offers two free collections of up to three large items (mattresses, couches, etc.) for single-family residents, and unlimited pick-ups for multi-family residents. The service picks up bulky items at residents' addresses after they call to make an 
appointment. Because the program is free, this suggests that the cost it not a barrier, but awareness may be.

The significant relationship between a high percent of non-English speaking individuals and increased dumping suggests that non-English speaking residents may not be aware of, or comfortable using the junk pickup program. The City of San José's Environmental Services Department provides outreach materials in Spanish, English and Vietnamese, but the delivery of these materials may need to be changed for non-English speaking communities. Outreach could be tailored to specific cultures in addition to languages to make it more accessible for non-English speaking residents. In addition, dumping was associated with low-income. A lack of access to technology such as computers and internet access could be causing an additional barrier for non-English speaking and low-income residents. Outreach about the junk item pick up program should be focused in non-English speaking communities through methods that do not require computers or internet.

Furniture may be dumped often due to high resident turnover. Increased dumping rates were found in areas with a high percentage of renters. Individuals who must move out of their residence in a short time frame may not have the time to properly transport their furniture, which forces them to leave it on the street. In addition, the junk pick up program is likely inconvenient for residents who need to move quickly. Junk pick-up appointments are set up to two weeks away from the time a resident calls for their appointment. Faster appointment turn-arounds could improve the ability for residents to utilize the junk pick-up program. From a broader perspective, decreasing resident 
turnover will limit the need for residents to move their items often. Improvements in affordable housing could provide more stable living situations for low-income residents leading to less turnover.

Garbage was the second most commonly dumped item. This finding was surprising because garbage bags can fit into residential waste bins or carts. Garbage was most commonly dumped in low-income block groups which suggests that households in lowincome areas are generating more trash than will fit into their residential carts. This could be due to high housing prices in the San José area, which often forces multiple families to live in a single-family home. The City of San José's "pay as you throw" system does not encourage residents to purchase additional garbage service. Previous studies have shown that pay as you throw systems cause increased rates of illegal dumping (Kim et al., 2008). Currently, San José residents are offered three sizes of garbage carts (32 gallons, 64 gallons, 96 gallons) at leveled prices $(\$ 32.07, \$ 64.14, \$ 96.21$ respectively) (City of San Jose, 2016). Garbage carts for single-family homes should be offered at a larger size for a subsidized price to households with higher than average household size.

\section{Illegal Dumping and Social Disorganization}

The significant relationship between percent renters, percent non-English speaking individuals, income, and mass of dumped debris per block group can be explained by the theory of Social Disorganization. The Social Disorganization Theory states that increased rates of crime are often found in communities with high rates of population turnover, cultural and racial heterogeneity, and poverty due to a decreased capacity to communicate when crime such as illegal dumping arises within a community 
(Bursik \& Grasmick, 1993; Kubrin \& Weitzer, 2003; Sampson \& Raudenbush, 1999).

In this study, high population turnover was represented by percent renters, while cultural and racial heterogeneity was represented by percent non-English speaking individuals, and median family income represented poverty levels. Increased rates of dumping in low-income communities with non-English speaking residents and high population turnover suggests that low-income communities in San José are unable to communicate with each other effectively. Inhibited communication leads to less community surveillance, and increased rates of crime. An inability to communicate could be explained by high rates of diversity which causes residents to speak many different languages, or because residents are very mobile and move in and out of communities often, affecting relationship building. Low-income residents are forced to move often because of an inability to purchase homes due to higher than average home prices.

Social disorganization can be improved in low-income communities of San José by improving housing opportunities and by fostering communication. Affordable housing for low-income residents would allow for less population turnover, along with increased communication and surveillance between residents. Increased communication can be encouraged through community events, and facilitated meetings between community leaders and groups. Community events will allow residents who speak the same languages to communicate more effectively. Facilitated meetings between community leaders and groups could allow a setting for residents that speak different languages to communicate with each other. 


\section{Illegal Dumping and Crime}

Not only does illegal dumping contribute to physical disorganization, but it is associated with higher crime rates. The positive relationship between dumping and crime suggests that communities with more illegal dumping also experience higher rates of crime. This finding suggests that illegal dumping could not only serve as a predictor for social disorganization, but also for crime. The success of specific efforts to improve community organization such as affordable housing and improved communication could be indirectly measured through illegal dumping on city streets. Cleaning up illegal dumping itself may not directly influence crime or social disorganization, but monitoring it could serve as an important predictor for community health.

\section{Recommendations}

The City of San José offers a free large item pick-up program, but the program is under-utilized, especially by non-English speaking residents. Culturally responsive outreach about the program in non-English speaking communities could encourage more use.

The City of San José should offer subsidized upsized garbage bins for single-family households with higher than average household sizes. This means that low-income single-family homes with more than one family living inside of them should be able to pay the lowest price for their garbage service, but receive service for the largest cart size.

Illegal dumping has the potential to serve as a physical indicator for community organization and crime. Illegal dumping rates should be monitored in all areas of San José to identify communities in need of additional support. Efforts to improve the social 
organization of communities could lead to decreased rates of dumping and other crime.

This can be achieved by improving community communication through affordable housing options, community events, and facilitated conversations between neighborhood leaders and groups 


\section{REFERENCES}

Biotto, G., Silvestri, S., Gobbo, L., Furlan, E., Valenti, S., \& Rosselli, R. (2009). GIS, multicriteria and multi-factor spatial analysis for the probability assessment of the existence of illegal landfills. International Journal of Geographic Information Science, 23(10), 1233 1244. doi: 10.1080/13658810802112128

Bullard, R. (1990). Dumping in Dixie: race, class, and environmental quality. Boulder, CO: Westview Press.

Bursik, R. J. (1988). Social disorganization and theories of crime and delinquency: problems and prospects. Criminology, 26(4), 519-551.

Bursik, R. J., \& Grasmick, H. (1993). Economic deprivation and neighborhood crime rates, 1960- 1980. Law \& Society Review, 27(2), 263-283.

Carmichael, S., \& Hamilton, C. V. (1967). Black power: the politics of liberation in America. New York: Vintage Books.

City of San Jose. (2016). Environmental services department: garbage rates. Retrieved from: http://www.sanjoseca.gov/index.aspx?nid=1551

City of San Jose. (2017). Data download: city limits [Data file]. Retrieved from: http://www.sanjoseca.gov/index.aspx?NID=3308

City of San Jose. (2014). Housing market update (quarter 3). San Jose, CA: City of San Jose.

Cole, L. W., \& Foster, S. R. (2001). From the ground up: environmental racism and the rise of the environmental justice movement. New York and London: New York University Press.

Comba, P., Bianchi, F., Fazzo, L., Martina, L., Menegozzo, M., Minichilli, F., Martuzzi, S. T. (2006). Cancer mortality in an area of Compania (Italy) characterized by multiple toxic dumping sites. Annals New York Academy of Sciences, 1076, 449- 461. doi 0.1196/annals.1371.067

Critto, A., Carlon, C., \& Marcomini, A. (2003). Characterization of contaminated soil and groundwater surrounding an illegal landfill by principal component analysis and kriging. Environmental Pollution, 122, 235-244.

Crofts, P., Morris, T., Wells, K., \& Powell, A. (2010). Illegal dumping and crime prevention: a case study of Ash road, Liverpool Council. Public Space: The Journal of Law and Social Justice, 5, 1-23.

Delgado, R., Stefancic, J., \& Liendo, E. (2012). Critical race theory: an introduction. New York, NY: New York University Press. 
Felice, B. D., Nappi, C., Zizolfi, B., Sardo, M. G., Bifulco, G., \& Guida, M. (2012). Telomere shortening in women resident close to waste landfill sites. Gene, 500, 101- 106. doi: 10.1016/j.gene.2012.03.040

Fullerton, D. (1995). Garbage, recycling, and illicit burning or dumping. Journal of Environmental Economics and Management, 29, 78-91.

Giovannini, A., Rivezzi, G., Carideo, P., Ceci, R., Diletti, G., Ippoliti, C., . . Scortichini, G. (2014). Dioxins levels in breast milk of women living in Caserta and Naples: assessment of environmental risk factors. Chemosphere, 92, 76- 84.

Glanville, K., \& Chang, H.-C. (2015). Remote sensing analysis techniques and sensor requirements to support the mapping of illegal domestic waste disposal sites in Queensland, Australia. Remote Sensing, 17, 13053-13069. doi:10.3390/rs71013053

Ichinose, D., \& Yamamoto, M. (2011). On the relationship between the provision of waste management service and illegal dumping. Resource and Energy Economics, 33, 79- 93. doi:10.1016/j.reseneeco.2010.01.002

Jorda-Borrell, R., Ruiz-Rodriguez, F., \& Lucendo-Monedero, A. L. (2014). Factor analysis and geographic information system for determining probability areas of presence of illegal landfills. Ecological Indicators, 37, 151- 160. http://dx.doi.org/10.1016/j.ecolind.2013.10.001

Karagiannidis, A., Xirogiannopolou, A., Leverenz, H., Tchobanoglous, G., Erkut, E., \& Voutsas, A. (2005). Investigation of key-factors influencing individual behavior and attitude towards/against illegal waste dumping and source separation activities under the frame of a potential pay as you throw system in Greece. Waste-The Social Context, Edmonton, Alberta, 319-328.

Kim, G.-S., Chang, Y.-J., \& Kelleher, D. (2008). Unit pricing of municipal solid waste and illegal dumping: an empirical analysis of Korean experience. Environmental Economics and Policy Studies, 9, 167- 176. doi: 10.1007/S10018-008-0144-3

Kinnaman, T. C. (1996). Garbage, recycling, and economic incentives. Lewisburg, PA: Bucknell University

Kubasek, M., \& Hrebicek, J. (2013). Crowdsource approach for mapping illegal dumps in the Czech Republic. International Journal of Spatial Data Infrastructures Research, 8, 144157. doi: 10.2902/1725-0463.2013.08.art7

Kubrin, C. E., \& Weitzer, R. (2003). New directions in social disorganization theory. Journal of Research in Crime and Delinquency, 40(4), 374- 402. doi:10.1177/0022427803256238 
Matos, J., \& Kristof Ostir, J. K. (2012). Attractiveness of roads for illegal dumping with regard to regional differences in Slovenia. Acta Geographica Slovenica, 52(2), 431- 451. doi: 103986/AGS52207

Matsumoto, S., \& Takeuchi, K. (2011). The effect of community characteristics on the frequency of illegal dumping. Environmental Economics and Policy Studies, 13, 177-193. doi: 10.1007/s10018-011-0011-5

Myers, N., Mittermeier, R. A., Mittermeier, C. G., Fonseca, G. A., \& Kent, J. (2000). Biodiversity hotspots for conservation priorities. Nature, 403, 853-858.

Pellow, D. N. (2002). Garbage wars: the struggle for environmental justice in Chicago. Cambridge, MA: The MIT Press.

Ratcliffe, M., Burd, C., Holder, K., \& Fields, A. (2016). Defining rural at the United States census bureau. Washington, D.C.: United States Census Bureau.

Rattansi, A. (2007). Racism: a very short introduction. Oxford, United Kingdom: Oxford University Press.

Sampson, R. J., \& Raudenbush, S. W. (1999). Systematic social observation of public spaces: a new look at disorder in urban neighborhoods. American Journal of Sociology 105(3), 603- 51.

Sampson, R. J., \& Raudenbush, S. W. (2004). Seeing disorder: neighborhood stigma and the social construction of broken windows. Social Psychology Quarterly, 67(4), 319-342.

Santa Clara Valley Water District. (2017). Watershed information [Watershed map]. Retrieved from: http://www.valleywater.org/Services/WatershedInformation.aspx

Sigman, H. (1998). Midnight dumping: public policies and illegal disposal of used oil. RAND Journal of Economics, 29 (1), 157- 178.

Steenbeek, W., \& Hipp, J. R. (2011). A longitudinal test of social disorganization theory: feedback effects among cohesion, social control, and disorder. Criminology, 49(3), 833868. doi: 10.1111/j.1745-9125.2011.00241

Tasaki, T., Kawahata, T., Osako, M., Matsui, Y., Takagishi, S., Morita, A., \& Akishima, S. (2007). A GIS-based zoning of illegal dumping potential for efficient surveillance. Waste Management, 27, 256- 267.doi:10.1016/j.wasman.2006.01.018

Tasaki, T., Matsui, Y., Kawahata, T., Osako, M., Takagishi, S., \& Morita, A. (2004). Analysis of geographic attributes and probabilities related to illegal dumping. Journal of the Japan Society of Waste Management Experts, 1-10.

Title 10 of Crimes Against the Public Health and Safety, California Penal Code $\$ 374.3$ (1872). 
United States Environmental Protection Agency. (1998). Illegal dumping prevention guidebook. Chicago, IL: United States Environmental Protection Agency, Region 5 Waste, Pesticides and Toxics Division.

United States Environmental Protection Agency. (2016). Volume to weight conversion factors [Data file]. Retrieved from https://www.epa.gov/sites/production/files/201604/documents/volume_to_weight_conversion_factors_memorandum_04192016_508fnl.p df

United States Census Bureau. (2010). American fact finder: census [Data file]. Retrieved from: https://factfinder.census.gov/faces/nav/jsf/pages/download_center.xhtml

United States Census Bureau. (2012, March 26). TIGER/Line Shapefiles [Data file] Retrieved from: https://www.census.gov/geo/maps-data/data/tiger-line.html

United States Census Bureau. (2015). American fact finder, American community survey [Data file]. Retrieved from: https://factfinder.census.gov/faces/nav/jsf/pages/download_center.xhtml

Wang, L. (2014). Sustainable bioenergy production. Boca Raton, London, New York: Taylor and Francis Group.

Webb, B., Marshall, B., Czarnomski, S., \& Tilley, N. (2006). Fly-tipping: causes, incentives and solutions. London: Jill Dando Institute of Crime Science, University College London.

Wilson, D. C. (2007). Development drivers for waste management. Waste Management and Research, 25, 198- 207. doi: 10.1177/0734242X07079149 